\title{
Modernizm Eleştirilerinin "Yok-Yer" Bağlamında Sinema Mekânı Kurgusunda Analizi
}

\author{
İ. Bâkır KANLI*, Melis BİLGİÇÇ*
}

\begin{abstract}
Öz
Tarih boyunca birbirleri ile sıkı bir etkileşim içinde olan mimarlık ve sinema, diğer tüm sanat türlerinde olduğu gibi toplumu ilgilendiren olaylarla birlikte şekillenmiştir. Son zamanlarda bu alanda yapılan araştırmaların artmasıyla mimarlık dünyasında sinemanın yeri hakkında birçok çalışma yapılmıştır. Bu çalışmada ise öncelikle sinema ve mimarlığın mekânsal açıdan birbirini etkileme biçimleri ele alınmış, ardından başlıca amacı mekânı biçimlendirmek, mekânı tasarlamak olan mimarlık disiplininin, mekânı ve mekân içinde yer alan "deneyim" in temsilinin en etkili yolu olarak görülen sinemayı etkileme biçimi tartışılmak istenmiştir. Her ölçekte yenilikçilik söylemi ile ortaya çıkan "20. yüzyıl modernizm"i her "yer" ve her "zaman" için geçerli genel bir yaklaşım halini almıştır. Çalışmada mimarlık ve sinemanın bu duruma karşı oluşturduğu eleștirel yaklaşımının mekânsal kurgusu incelenmiştir. Bu bağlamda çalışmanın amacı; modernist toplumun ve onun yaşam şeklinin oluşturduğu "yok yer" kavramı eleştirisinin mekân kurgusunda nasıl ele alındığını göstermektir. Farklı türlerde gruplanarak seçilen filmlerde kurgulanan mekânlar; tema, olay kurgusu, gerçek mekân-hayali (kurgusal) mekân gibi farklı temsil biçimlerine göre analiz edilmiştir.
\end{abstract}

Anahtar Kelimeler: Sinema, Mekân, Yer, Yok-Yer, Mimari Kimlik

DOI: http://dx.doi.org/10.17336/igusbd.95922

${ }^{*}$ Yrd. Doç. Dr., Marmara Üniversitesi, Siyasal Bilgiler Fakültesi, Siyaset Bilimi ve Kamu

Yönetimi Bölümü Öğretim Üyesi, E-posta: bkanli@yahoo.com

${ }^{* *}$ Ar. Gör., İstanbul Gelişim Üniversitesi, Mühendislik Mimarlık Fakültesi, Mimarlık

Bölümü, E-posta: melis.7.bilgic@gmail.com 


\section{An Analysis of Criticisms of Modernism in the Context of "Non-Place" Through Cinema-Space Fiction}

Sayfa/Page | 118 İGÜSBD Cilt: 3 Sayı: 1 Nisan / April 2016

\section{Abstract}

Being intensively interacted with each other architecture and cinema are shaped by the societal developments throughout the history as in the other kinds of art. With the recent increase in the research there have been conducted various studies analysing the role of cinema in architecture. This study, first, deals with the form of spatial interactions between film and architecture. Yet, the main objective of the article is to discuss in which ways the architecture aiming the form and shape the space influences the cinema that is seen as the most effective way to represent the space and the "experience" located in the space. Modernism of the $20^{\text {th }}$ century that emerged with the discourse of innovation in all scales has become a general approach for every "place" and every "time". In this study, spatial fiction of critical approach that architecture and cinema form against this situation is examined. In this regard, the purpose of the study is to demonstrate how critical of "non-place" notion that formed by modernist society and life style are handled. Cinema spaces, which are selected from films in different categories, were analysed according to different representation formats such as theme, event fiction, and real space-imaginary (fiction) space.

Keywords: Cinema, Space, Place, Non-Place, Architectural Identity

\section{Giriş}

Kester Rattenbury "film mimarlığın varlığını gözlemlemektedir" der. ${ }^{1}$ Sinema ve mimarlık kavramsallaştırma, tasarlama, üretme ve sunma teknikleri açısından birbirine yakın disiplinlerdir. Aslında bu iki disiplinin de yine iki temel boyutu vardır ve hikâyesini bu şekilde anlatır: "zaman" ve "mekân". İki sanat dalı da bir senaryo dâhilinde belirli bir mekân ve zamanda gerçekleşir. Sinema da başarılı bulduğumuz filmler genelde bize mekân duygusunu en iyi veren ve zaman faktörünü en iyi kullanan filmlerdir. Mekânı kullanmak da mimarlı̆̆ın özü olarak bilinmektedir. ${ }^{2} \mathrm{Bu}$ sebepten ötürü mimarlık dünyasında sinemanın önemli bir yeri vardır. Mimarlığın sinemayla olan ilişkisinin diğer sanat türlerinden daha yoğun olmasının sebebi izleyiciye mekânı görsel olarak sunmaktan ziyade duyusal olarak aktarma konusundaki

${ }^{1}$ K. Rattenbury, Echo and Narcissus, in Architecture \& Film, Ed. M. Toy, Architectural Design Profile 112, vol. 64 (12), 1994, pp. 7-35.

${ }^{2}$ Atilla Dorsay, "Mimarlık Hayatlarımızı Somut Olarak Biçimleyen Bir Sanat...", 2013, www.yapi.com.tr (Erişim Tarihi: 31.12.2014). 
başarısıdır. Sinema ile mimarinin yoğun ilişkisi, temelde gerçeklik tanımı ve temsiliyet üzerinde yoğunlaşmaktadır. Sinemanın günümüzde düşlenenin bile kolaylıkla ifade edilebildiği bir "temsil" șekli olduğunu varsayabiliriz. Aynı zamanda sinema ve mimarinin ilişkisini güçlendiren bir diğer ortak yanları ise "varlık ve mekân" ilişkilerinin yorumlanışındaki değişimin tartışılmasına olanak veriyor olmasıdır. Sinema, mekânı sadece geometrisine dayalı olmayan dinamik, her an yeniden tanımlanabilir, içinde yaşanan, zamanbağımlı deneyimlerle ele alır. Bu birbirinden farklı mekân tanımları ya da deneyimleri, mimarlıkta tasarlanan nesneyi insandan, insanı da nesnesinden bağımsız kılan bir yaklaşımın tersine, her ikisini, birbirini etkileyen ilişkiler içerisinde bir bütün olarak ele alan bir anlayış ile ortaya koyar ve bu noktada sinema, bu karşılıklı ilişkiyi temsil etme yeteneği olan şiirsel bir ortamı ve önemli, ayrıcalıklı bir aracı bizlere sunmuş oluyor. ${ }^{3} \mathrm{Bu}$ şekilde bu yaklaşımların mekânı da bir deneyim olarak ele aldığı düşünülmektedir.

Mimarlık, tüm tasarım işlerinde olduğu gibi, düşlenen ya da imgelenenin gerçekleştirilme aracı olurken sinemanın, öncelikle düşlenenlerin temsilinde diğer ortamlardan çok daha zengin ve farklı bir araç sunduğu düşünülmektedir. Le Corbusier'nin Villa Savoye'u filmle anlatmak istemesi de bunun bir örneğidir. Bu iş için P. Chenal'le anlaşır ve burada villanın rampasını tırmanıp çatı bahçesine giden bir kadın ile binanın deneyimlenmesi anlatılmak istenir. Le Corbusier zaten mimarlığ diye kelimelendirerek hareket ile yaşanan bir olgu olarak tanımlamıştır. ${ }^{4}$

Bu çalışmanın amacı mekân tasarımını uğraş edinen mimari ile kendi kurgusunu oluştururken mekân ve mekân deneyimini kullanan sinemanın karşılıklı etkileşiminin temsili mekânlar üzerinden incelenmesidir. Salt biçimsel öğelerin dışında mekân algısının ve dinamizminin önemini vurgulayan sinemanın, 20.yy modernizminin oluşturduğu "yok-yer" lere karşı eleştirel yaklaşımının mimari unsurlardan da destek alarak hangi şekillerde mekânlara yansıtıldığını analiz edilmiştir. Bu çalışmada sinema yoluyla, seyirciye "yer algısını", "yer kimliğini”, "yere bağlılığı”, "farklılığı"; "yok yer", "kimliksizleşme" ve "yabancılaşma" kavramları üzerinden oluşturulmuş temsili mekânlara nasıl aktarıldığı araştırılmaya çalışılmıştır. Mimarlık ve sinema ilişkisini mekân temsilleri üzerinden incelenmesi amaçlanmıştır.

\footnotetext{
${ }^{3}$ Belkıs Eroğlu, "Hayalle Hakikat Arasında Bir Yerde", 2011, http://www.hayalperdesi .net/dosya/85-hayalle-hakikat-arasinda-bir-yerde.aspx (Erişim Tarihi: 02.01.2014).

${ }^{4}$ Le Courbusier, Bir Mimarlığa Doğru, Yapı Kredi Yayınları, İstanbul, 2015, s. 85.
}

Sayfa/Page | 119

İGÜSBD

Cilt: 3 Sayı: 1

Nisan /

April 2016 
Sayfa/Page | 120 İGÜSBD Cilt: 3 Sayı: 1 Nisan / April 2016

Bu çalışmada özellikle Tanyeli'nin oluşturduğu tablo referans alınarak gerçek sinemada kullanılan gerçek mimari mekânlarla beraber, sadece film için oluşturulan kurgusal mekânlar hem bu mekânların oluşturulma biçimi hem de kullanım biçimi göz önünde tutularak incelenecek filmler seçilmiştir. ${ }^{5}$ Filmlerde kurgu ile mekânsal ilişkilerin hangi bağlamda ve nasıl kullanıldığ irdelenmiştir.

Çalışmada yöntem olarak öncelikle literatür taraması ve basında çıkan değerlendirmeler üzerinden toplanan veriler değerlendirilmiş ve örnek olarak seçilen filmler üzerinden mekân analizi yapılmıştır. Sinemada vazgeçilmez olan mekân kavramı "sinema mekânı" olarak farklı șekillerde üretilmekte, kullanılmakta ve izleyiciye sunulmaktadır. Mekânın filmde kullanım biçimleri, örnekler üzerinden aktarılmıştır. Örnek filmler, Tanyeli(2001)"nin sinema ve mimarlık ilişkileri üzerine yapmış olduğu sınıflandırmadan yola çıkılarak, modernizm eleştirisi olarak ortaya çıkan "yok-yer"leri temsil eden mekânların üretim biçimi ve kullanım biçimi üzerindeki farklılıkları anlatmak üzere seçilmiştir. Seçilen filmler 3 farklı grupta ele alınmıştır;

- Bala'nın (2007) yaptığı tanımlamalar doğrultusunda "Doğrudan tema olarak " yok yer" eleştirisini işleyen filmler" örneği olarak Terminal,

- Kutucu'nun (2003) yaptığı tanımlamalar doğrultusunda "Doğrudan mekân ve olay kurgusu kullanılarak yapılan "yok yer" eleştirisi "örneği olarak Dövüş Klubü,

- Güleç'in (2004) yaptığı tanımlamalar doğrultusunda Gerçek ve hayali mekân zıtlı̆̆ı kullanılarak yapılan " yok yer" eleştirisi örnekleri olarak Tim Burton'ın Makas Eller, Charlie'nin Çikolata Fabrikası, Alice Harikalar Diyarında, Ölü gelin, Batman dönüyor.

Belirlenen mekân temsili şekillerine göre seçilen örnek filmler üzerinde karelerin dondurulması yöntemiyle elde edilen temsili mekân görüntüleri yukarıda belirtildiği gibi üç farklı sinema filmi grupları mekânın üretim biçimi (gerçek mekân, kurgu mekân) ve mekânın kullanım biçimleri bakımından getirdikleri modernizm eleștirilerinin yok-yer kavramını karşılaştırılmıştır.

5 U. Tanyeli, "Sinema ve Mimarlık: Temsiliyet Nesnenin Temsili Sanatın Sanallıkla İfadesi", Arredamento Mimarlık, 11, 66, 2001. 


\section{Modernizm ve "yer" ilişkisi}

"Modern" kavramı, "içinden yaşanılan günlere uygunluk" anlamında ayrıca "yeni, yenici, ilerici, çağdaş, çağcıl" anlamlarında da kullanılmaktadır.6 Gündelik yaşamda modaya uygun tutumlar, ister "olumlu" ister "olumsuz" olsun "modern" olarak nitelendirilmektedir. Avrupa'da 1750'lerde endüstri ve sanayi gelişimi ile başlayan yaşama biçimi, ilişkileri, malzeme, teknoloji, yeni ve büyük boyutlu yapı tiplerine duyulan gereksinim, kentleşme nedeniyle ve özellikle yeni üretim biçimleri ile tüm toplumu içine alan değiş̧im ve biçim arayışları "modern" olarak adlandırılmıştır. Bu yeni dönemin, mimarlık dünyası ve diğer tüm tasarım ve sanat dallarında kendini göstermektedir. Modernizm, işlev üstünlügü, seri üretim teknikleri, süsleme ve yapım teknikleri gibi konular başta olmak üzere 19. yy mimarisinin geleneksel ve tarihsel yaklaşımına zıt olarak mimarlık dünyasına girmiștir.

Artık 1920'lerde "modern mimari hareket" olarak adlandırılan bu akımın başlıca amacı mimariyi arıtmak, üslup fazlalıklarını ayıklamak ve evrensel bir dil oluşturarak "yeni" ve "taze" bir başlangıç noktası sağlaması düşünülen "yalın" ve "dolaysız" bir mimariye dönmesidir. Sanayi ve teknolojik gelişmelerin mimariye etkisi "makine estetiği" kavramını doğurmuştur. Mimaride "makine"nın geometrik, süssüz biçiminin herkesin anlayacağı, evrensel bir dil yarattığı düşünülmüştür. "Rasyonalizm" ve "evrensellik" ilkeleriyle öne çlkan modernizm, sadece mimari alanda değil birçok sanat türünü etkilemiştir.7 Bu makalenin çalışma konusu olan sinema mekânına etkisi yapılan modernizm eleştirileri üzerinden incelenmiştir. Literatürde sinemanın doğası gereği modernizmin sanat kalıplarına uymayan yanlarına da değinilmektedir. Diğer yandan sinemada kurgunun varlığı da modern anlayışın sadelik, saflık ilkelerini ortadan kaldıran bir unsur olarak değerlendirilmektedir. Michael Fried'ın da dediği gibi "Sinema en deneysel biçimde bile modernist bir sanat değildir" sözü de modernizm ve sinemanın çatışmasını özetlemektedir. ${ }^{8}$

Geleneksele karşı yenilik düşüncesiyle ortaya çıkan modernizm getirdiği kurallarla genellik temel tasarım prensiplerinden biri haline gelmiş ve bununla birlikte modernizm, yeni bir geleneksellik tanımlamaya başlamıștır.

${ }^{6}$ D. Ceyhun, "Modern, Kavramı ve Mimarlık", Yapı Dergisi, 248, 2002, s.54-57.

${ }^{7}$ A. Touraine, Modernliğin eleștirisi, Modernist ideoloji, (çev. Hülya Tufan), 4.bs., Yapı Kredi Yayınları, İstanbul, 2002, s.26-38.

8 Perry Anderson, Postmodernitenin Kökenleri, (çev. Elçin Gen), İstanbul: İletişim Yayınları, 2005.

Sayfa/Page | 121

İGÜSBD

Cilt: 3 Sayı: 1

Nisan /

April 2016 
Modernizm 20. yüzyll itibariyle tüm kültürleri içine alacak kadar genişleyip anlamını yitirmeye başlamıştır. Bu da kimliksiz, durağan ve sabit bir "yer" ve "kimlik" olgusu doğurmuştur. Kuramsal yaklaşımlar incelenecek olursa; Sennett'e göre kimlik, insanların kendilerini başkalarına karşı tanımlamalarıdır9. Diğer taraftan, Heidegger yaşamın özü olarak "yuva" (özel

Sayfa/Page | 122 İGÜSBD Cilt: 3 Sayı: 1 Nisan $/$ April 2016 bir tür 'yer') kavramını gördüğünden kimlik meselesini "aidiyet ve yerleşiklik olgusu" etrafında tartışır ve "özgünlük" kavramına bağlar.10 Laclau ve Mouffe ise kimliği, farklılık üzerinden tanımlar ve bu kavramı "kimlik kaygandır ve her an yeniden kurulur; sabit bir konum değil, tersine dünyayı ve kendimizi tanımladığımız geçici bir platformdur; kimliğin oluşumunda "farklılık" temel rolü oynar, çünkü kimlik ancak, başka kimliklerle olumsuzluk ilişkisi içinde, başka kimliklerle farklılıkların kalıcılaştırılması yoluyla kurulabilir" șeklinde yorumlamaktadır.11

Bu düşünce sistemine göre "yer" olgusu farklı kimliklerin durmaksızın yeniden oluşup evrildiği, bu kimliklerin aralarındaki yeni beliren ilişkiler tarafından koşullanan ve deneyimsel bir olgudur. ${ }^{12} \mathrm{Bu}$ düşünsel bağlamda kimlikler artık yerlerinden kaynaklanan, yere bağlı ve bağımlı değil, yerden görece bağımsız kimi zaman yere karşıt biçimde yeniden yapılanan oluşumlardır. ${ }^{13}$

Tanyeli de yerin coğrafi sınırların çok ötesinde bir kavram olduğuna dikkat çeker. ${ }^{14}$ Bununla birlikte modernizmin kentsel, mekânsal ve bireysel ölçekteki etkilerini belgeleyip aktarması açısından sinemanın "modernliğin hafızası" olduğu savunulmuştur. Ancak sinema, her ölçekte yenilikçilik söylemi ile ortaya çıkan modernizmin her yer ve her zaman için geçerli coğrafi sınırlar içinde genel bir yaklaşım halini almasına eleştirel yaklaşmıştır. ${ }^{15}$

${ }^{9}$ Richard Sennett, Gözün Vicdanı, Kentin Tasarımı ve Toplumsal Yaşam, (çev: S. Sertabiboğlu ve C. Kurultay), İstanbul: Ayrıntı Yayınları, 1999.

${ }^{10}$ Martin Heidegger, Poetry, Language, Thought, (çev: Albert Hofstadter), New York: Harper \& Row, 1971.

${ }^{11}$ Lionel Boxer, "Assessment of Quality Systems with Positioning Theory", The Self and Others: Positioning Individuals and Groups in Personal, Political and Cultural Contexts, (Ed. R.Harré ve F. Moghaddam), Westport: Praeger Publishers, 2003, s.251-277.

12 Gilles Deleuze, Felix A. Guattari, Thousand Plateaux: Capitalism and

Schizophrenia, London: Athlone Press, 1987.

13 Jeff Malpas, Place and Experience: A Philosophical Topography, Cambridge: Cambridge University Press, 1999.

${ }^{14}$ Uğur Tanyeli, "Yer, Yer-Olmayan, Naziler, Auge ve Akla Getirdikleri", Arredamento Mimarlık, no. 5, (2012), ss.106-111.

15 Gülşah Güleç, "Modernizm Eleștirileri”, 2013, http://www.mimarlikdergisi.com/ index.cfm?sayfa=mimarlik\&DergiSayi=389\&RecID=3303 (Erişim Tarihi: 31.12 .2014 ) 
$\mathrm{Bu}$ konuda düşünmenin yolunu açmak için zaman-mekân kavramı kullanılmıştır: Mekânın temsil edilebildiği varsayımının genel geçer, bir hakikat hâline gelmediği bir durumun kavramından bahsedilmek istenmiștir. Temsil iddiası, değişmez ve tarih dışı bir alanın varlığından güç alır; bu da beraberinde zamansızlaşmayı getirir.

\section{Sinema ve mimarlık ilişkisinin "yer" bağlamında incelenmesi}

Mekân ve mimarlığın temel hedefi olan "yer" tasarımı, fiziksel boyutun ötesinde duyular, deneyimler ve kişisel bağlamlar doğrultusunda ele alınmalıdır. Buna bağlı olarak coğrafi ve sosyo-kültürel bağlam da göz ardı edilmemelidir. Mimarlığın temel hedeflerinden olan tanımlanmış mekân "yer" oluşturma, sinemanın da sunduğu bir olgudur. Bu anlamda sinema mekânında farklı biçimlerde "yok yer"lerin "yer"e dönüștürülebilme özelliği mimarların ilgisini çekmektedir.

Tanımlanmış mekân olarak tanımlanan "yer"in oluşumu, sinema ve mimarlığın mekân üzerinden kurduğu ortak değerlerdir. Mimarlar için film; mekân ve zaman boyutuyla mimariyi vurgularken, görüntü aktarımıyla uğraşan sinemacılar için ise görsel çevre dinamikleri ve özellikle mimari önemlidir. Mekân-zaman kurgusu ve etkileşimi mimarlık ve sinema disiplinlerini eklemleyen yapı taşları olarak her iki disiplinin birbirine olan ilgisinin belirgin özelliğini oluşturmaktadır. ${ }^{16}$ Kısacası her iki sanat dalı da kurgulanan bir senaryo bağlamında yeni bir gerçeklik üretmektedir. Oluşturulan gerçeklik ve yer bağlamında modernizm konusu tekrar ele alındığında sinemanın mekân kurgusuyla modernizmin ve bu kavramın getirdiği katı yer kurallarına nasıl davrandığı incelenmeye çalışılmıştır. Bu da en başta etrafımızdaki fiziksel ve kültürel bağlamın sorgulanmasını gerekli kılmıştır. Bu sorgulama da beraberinde modernizmin oluşturduğu zorlama "kimlik" ve "yer" kavramlarına eleştiri getirmiștir. Çünkü hem sinema hem de mimari için insanın bir mekânla kurduğu bağ o mekânı yere dönüştürür ve mekâna bir kimlik kazandırır.

Bu eleştiri şekli 20.yy ' da birçok filmde konu olarak işlenmiştir. Ancak her sanat türünde olduğu gibi sinemada da bu konuyu ele alış şekli farklıdır. Sinema Ek Şekil:1'de gösterildiği gibi kendini besleyen ana unsur olarak

${ }_{16}$ Havva Bala, "Sinemada Mimari Okumaları", 2014, http://saklisinema.com/index. php/2014/10/16/sinemada-mimari-okumalar/ (Erişim Tarihi: 31.12.2014).

Sayfa/Page | 123

İGÜSBD

Cilt: 3 Sayı: 1

Nisan /

April 2016 
gerekli olan "mekânı", mevcut mekânı kullanması" veya "kurgusal mekânı

oluşturması" gibi basitçe iki yolla oluşturmakta olduğu söylenmektedir.

Sayfa/Page | 124

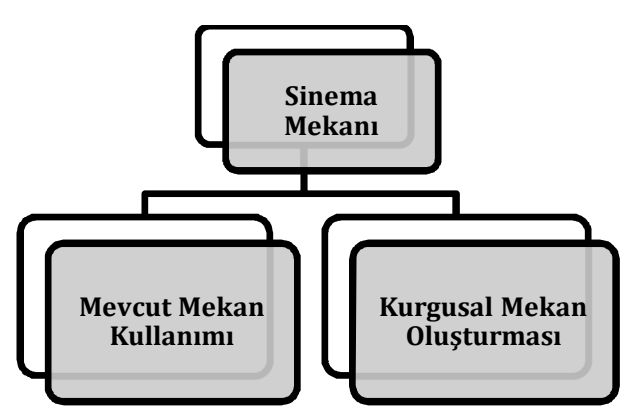

Şekil 1. Sinema mekânı oluşumu

\section{Seçilen filmler ve mekân analizi}

Sinema mekânın kurgulanma şekline göre farklı türlerde incelenmiştir. Tanyeli'ye göre sinema ve mekân arasında 3 farklı tür ilişki-etkileșim olduğu görülmüştür. ${ }^{17}$

- "İnşa edilmemiş"(unbuilt) ve gerçekte var olmayan sanal mimari mekânlar,

- Kendi sanal evreninde "gerçek" mimari mekânlar üreten sinema mekânları,

- "Bir kişilik olarak mimarlara ve onun / onun mimari faaliyetleri"ni esas alarak oluşturulan sinema mekânları ${ }^{18}$.

Bu çalışmada Tanyeli'nin (2001) sinema ve mimarlık arasındaki ilişki üzerine belirttiği tanımlar ve yöntem kısmında bahsedildiği üzere sırasıyla Bala (2007), Kutucu (2003) ve Güleç, Çağlar (2014)'ın tanımları doğrultusunda aşağıdaki ek tablo:1'de gösterilen filmler mekânın üretim ve kullanım biçimlerine göre analiz edilmiştir.

17 U. Tanyeli, "Sinema ve Mimarlık: Temsiliyet Nesnenin Temsili Sanatın Sanallıkla İfadesi", Arredamento Mimarlı, 11:66, 2001.

${ }^{18}$ Havva Bala, "Reading of the Architectural Identity Via Cinema", Cinej Cinema Journal, sayı: 4.1 no: 81, 2014. 


\begin{tabular}{|c|c|}
\hline $\begin{array}{c}\text { MEKÂNI ÜRETME VE } \\
\text { KULLANMA BIÇiMİ }\end{array}$ & FILMLER \\
\hline $\begin{array}{c}\text { Doğrudan tema olarak "yok yer" } \\
\text { eleştirisini işleyen filmler }\end{array}$ & Terminal \\
\hline $\begin{array}{c}\text { Doğrudan mekân ve olay kurgusu } \\
\text { kullanılarak yapılan } \\
\text { "yok yer" eleştirisi }\end{array}$ & Dövüş kulübü \\
\hline $\begin{array}{c}\text { Gerçek ve hayali mekân zıtlığı } \\
\text { kullanılarakyapılan "yok yer" } \\
\text { eleştirisi. }\end{array}$ & $\begin{array}{c}\text { TIM BURTON FíLMLERİ } \\
\text { (Makas Eller, Charlie'nin Çikolata } \\
\text { Fabrikası, Alice Harikalar Diyarında, } \\
\text { Ölü gelin, Batman dönüyor) }\end{array}$ \\
\hline
\end{tabular}

Tablo 1. Seçilen filmlerin analiz yönteminin gösterilmesi

\subsection{Doğrudan tema olarak "yok yer" eleştirisini işleyen filmler}

Görselliğin ön planda olduğu sinema ve mimarlık gibi disiplinlerde genellikle kavramsal boyut göz ardı edilmektedir. Ancak her filmin ana kurgusunu oluşturan mekânların şekillenmesini sağlayan bir teması vardır ve bu kavramlar mekânı oluşturan fiziksel unsurlar kadar önemlidir. Sinema, mekânı bir tema üzerinden yorumlar. Bu bölümde "yok yer" eleştirisini doğrudan tema olarak alıp gerçek mekânlar içinde işleyen terminal filminin mekân analizleri yapılmıştır.

Norberg-Schulz'a göre insanoğlu, varolduğu günden beri "varlığın özünü gösteren" yerler olușturma eğilimindedir.19 Mekân ile yerin organik bağı yerin ruhundan (genius loci) kaynaklanmaktadır. Yer olgusunu "ikamet etmek" üzerinden açıklayan Heidegger, insanın yaşamı boyunca gökyüzü ve yeryüzü arasındaki mesafeyi kullanarak, güvenli bir şekilde ikamet edebileceği yerler oluşturduğunu ifade etmektedir. İnsan evrensel kaos içinde bir yer tariflemek ve kaosa kendi aklının alabileceği düzeni getirmek ve bu düzen içinde kendi yerini belirlemek zorundadır. ${ }^{20}$

${ }^{19}$ Norberg-Schulz'dan aktaran: Havva Bala, "Mimarlıkta yok yer kavramı ve Terminal", 2014, http://www.boyutpedia.com/1613/69627/mimarlikta-\%E2\%80\%9Cnon-lieu \%E2\%80\%9D-kavrami-ve-terminal [Erişim: 04.01.2015]

${ }^{20}$ Heidegger'den aktaran K. Senem Koca, “Çağdaş Mimarlıkta Yersizlik", İstanbul: İ.T.Ü. Fen Bilimleri Enstitüsü, 2005 (Yüksek Lisans Tezi). 
Sayfa/Page | 126 İGÜSBD Cilt: 3 Sayı: 1 Nisan / April 2016

Modernizmin karmaşasıyla birlikte kimliksiz mekânlar oluşmuştur. Modern çağa özgü mekân tipolojilerini irdelerken Ek Resim:1 ve Ek Resim:2'de örnekleri görüldüğü gibi, havaalanı, otoban, süpermarket, alışveriş merkezi, otel odası gibi mekânların, yok-yer içerdiğini ya da tanımladığını ileri sürülmektedir. Bunun yanında yer-olmayanlara (yok-yer); alışa geldiğimiz mekân çeşitlerine benzemeyen ekspres yolları, bankamatikler, havaalanları gibi insanların ve yüklerin hızlandırılmış dolaşımı için inşa edilmiş yerler veya mega alışveriş merkezleri örnek verilmiştir.

Yok yerlerle ilgili olarak anılardan ve anı biriktirmekten söz etmek mümkün değildir, kısacası geçmişten bahsedilmez. Bu yerlerin "yok mekân" olarak adlandırılmasını sağlayan temel özellikleri belirli bir amaç doğrultusunda kullanılıyor olmalarıdır. Yapının ve ya yapıyı oluşturan mekânın işlevi öylesine mekâniktir ki, mimari tasarımda aynı şekilde şekillenmiştir. Yok mekân bulunduğu bölgenin coğrafi kültürel ve yerel değerler gibi karakteristiklerinden bağımsızdır. Mekâna sahip olma hakkı, bir alanın işaretlenmesi veya kişiselleştirilmesi, temel fizyolojik ihtiyaçlardan estetik hoşnutluğa kadar pek çok isteğe cevap vermeden, yoksunluk ve yersizyurtsuz olma halini doğurmaktadır. ${ }^{21} \mathrm{Bu}$ araştırma da ise yok yer kavramı, yer duygusu olmayan mekânlar, yer duygusunun insanları tutucu halinden uzaklaştırması çerçevesinden incelenmiştir. Yok yerlerin yeniliklere açı olmaya zemin hazırladığı düşüncesi, sinema filminin mekânsal kritiklerinden elde edilmiştir.22

Bu filmde konu yersiz bir insanın Augé'nin tanımladığı süpermodernite çağına özgü mekân tipolojilerinden olan ve "yok-yer" diye adlandırılan bir mekândaki deneyimlerini yansıtmaktadır. Film hem katı düzen sonucu yersiz kalan bir insanın bir mekâna sıkışıp kalması konusunu işlerken hem de bir yandan insanların sadece geçiş mekânı olarak kullandığı terminali kendine göre düzenleyip, bir kimlik kazandırarak "farklılık" katmasını anlatmaktadır. Gerçek mekânları barındıran "Terminal" filmi bu araștırma içinde "yok yer" kavramının üretkenlikle değiştirilmeye zemin olması halini yansıttığı için seçilmiştir. $\mathrm{Bu}$ şekilde "yok yer" leri katı düzenlerini, mekânik organizasyonlarını bir şekilde yansıtırken bir yandan da insanların bunu nasıl değiştirip kimlik kazandırabileceklerini göstermiştir. Yaşama ve eve dair tüm

${ }^{21}$ Havva Bala, "Mimarlıkta yok yer kavramı ve Terminal", 2014, http://www.boyutpedia.com/1613/69627/mimarlikta-\%E2\%80\%9Cnon-lieu\%E2\% 80\%9D-kavrami-ve-terminal [Erişim: 04.01.2015].

22 Gül Kale, "Antonioni'den Godard'a Filmlerdeki Mekân İmgelerinin Duyumsattıkları", Arredamento Mimarlık, sayı: 169, 2004, s.102. 
mekânsal düzenlemeler ve eylem alanları bu yok-mekân olan terminalde oluşturulabileceği gösterilmiștir.

Özde yersiz-mekân olan terminali bir "yer" e dönüştürmüştür. Yer duygusu veren mekânlarda bireyin sezgilerinin kaynağı ve onu yönlendiren şey olgunun kendisidir. Yerin deneyimi, duygu ve düşünce birliğini harekete geçiren ortamın oluşturulması sonucu gerçekleşmektedir. Karşılıklı olarak birbirine dönüşen ve ayrılmaz şekilde birbiri yerine geçen algılama ve hayal kurma edinimi de deneyimsel pratiği güçlendirmektedir. ${ }^{23}$ Böylece "terminal binası" sadece misafir kabul edilen bir yapıyken bir "ev (yuva)"e dönüştürülmüştür. $\mathrm{Bu}$ filmin modernizme eleştirisini şu şekilde açıklayabiliriz: Materyalist modern yaşantı, simgesel gerçeklerin yaşanması, verimliliği düşürmektedir. Bireyi benimsemediği, ilişki kuramadığı mekânlar içinde yaşamaya zorlamaktadır. Modern insanın beton bloklara ve kentsel yaşama mahkûmiyeti ile o insanın terminal binasında sıkışıp kalması içerik olarak aynıdır.

Ek Resim:1'de görüldüğü gibi “yok mekân” sayllan terminalde en göze çarpan koşuşturma içindeki kalabalıktır. Ek Resim:2'de görüldüğü gibi yüksek tavanlı metal soğuk bina mimari özellikleriyle tipik bir terminal binasıdır. Yapı, kameranın 360 derece açıyla kahramanın gözünden anlatılmaya çalışılmıştır. Ek Resim:3'de terminalin içindeki herkes tarafından bilinen ve yoğun kullanılan markaların satış birimleri ve havaalanının her tarafının reklam unsurlarıyla kaplı olması dikkat çekmektedir.

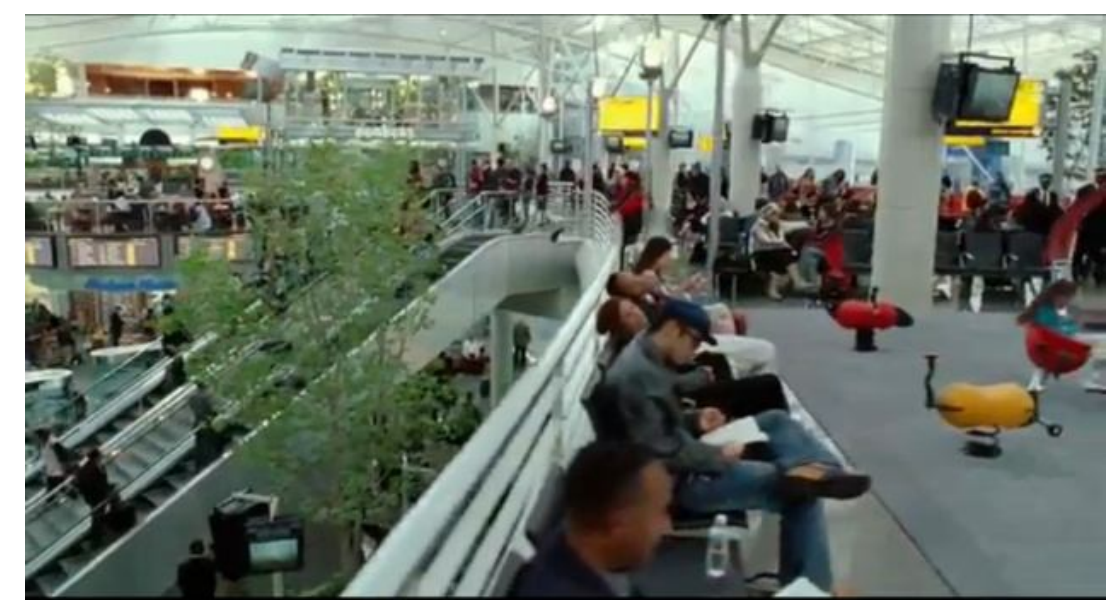

Resim 1. "Yok yer" olarak adlandırılan “terminal” iç mekânı

${ }^{23}$ Bala, a.g.m.

Sayfa/Page | 127

İGÜSBD

Cilt: 3 Sayı: 1

Nisan /

April 2016 


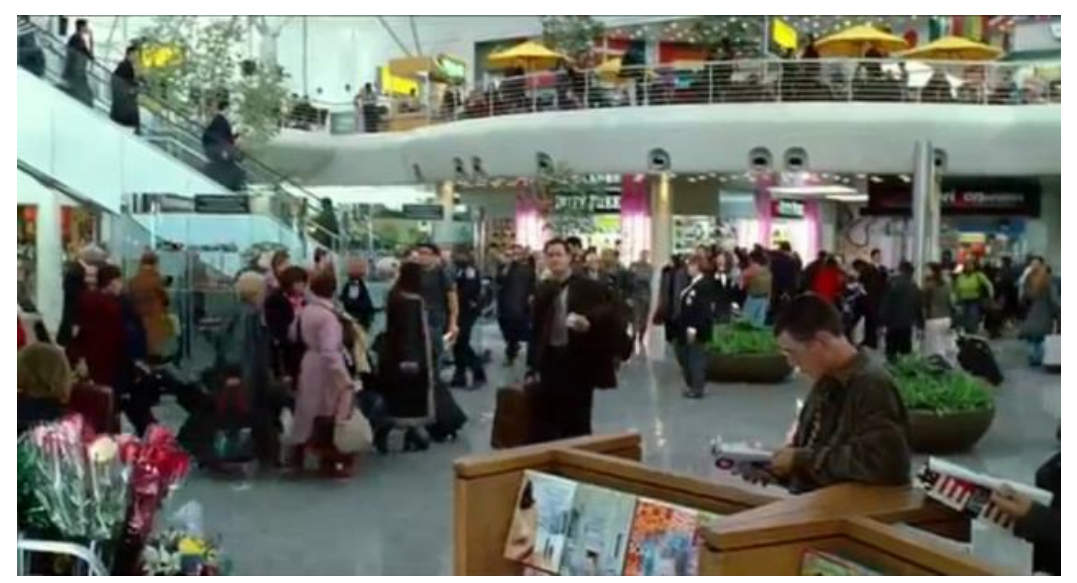

\section{Resim 2. Terminalin kullanıcıya sağladığı tek işlev olan alışveriş (satış birimleri-reklamlar)}

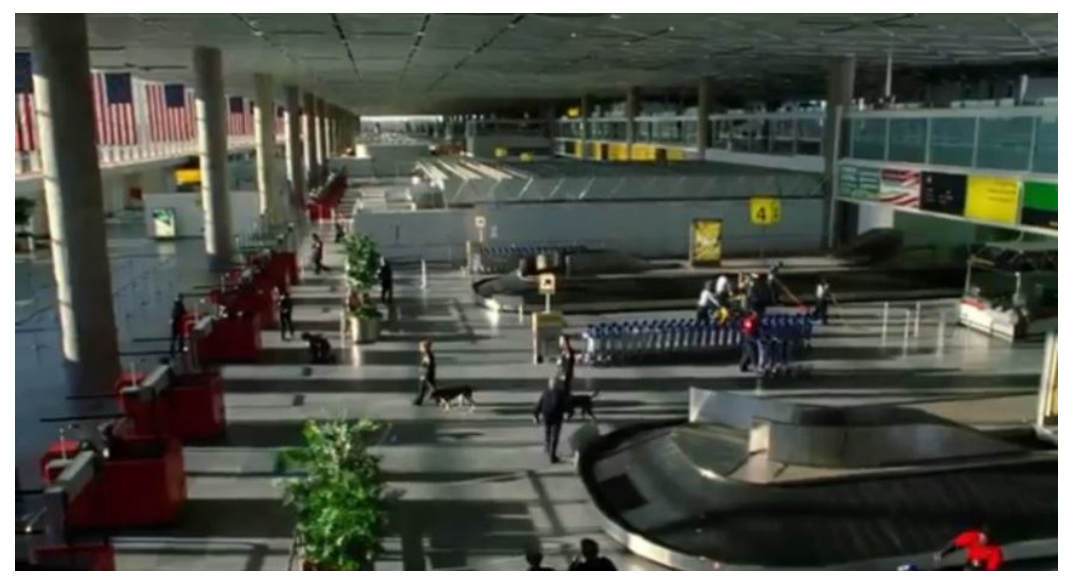

\section{Şekil 3. Terminal binası mimari özellikleri}

Tüm bu kapitalist unsurların dışın da kalan kahraman, bekleme salonu koltuklarını birleştirerek kendine yatak yapmış; boş arabaları ve düşen jetonları toplayarak para kazanmış; havaalanındaki kamusal tuvaletleri özel banyosu gibi kullanmıştır (Ek Resim:4). Transit yolcu salonunda binlerce kişiye aldırmadan bornozuyla dolaşırken, iş başvurusu için doldurduğu forma terminalin telefon numarasını yazmıștır. 

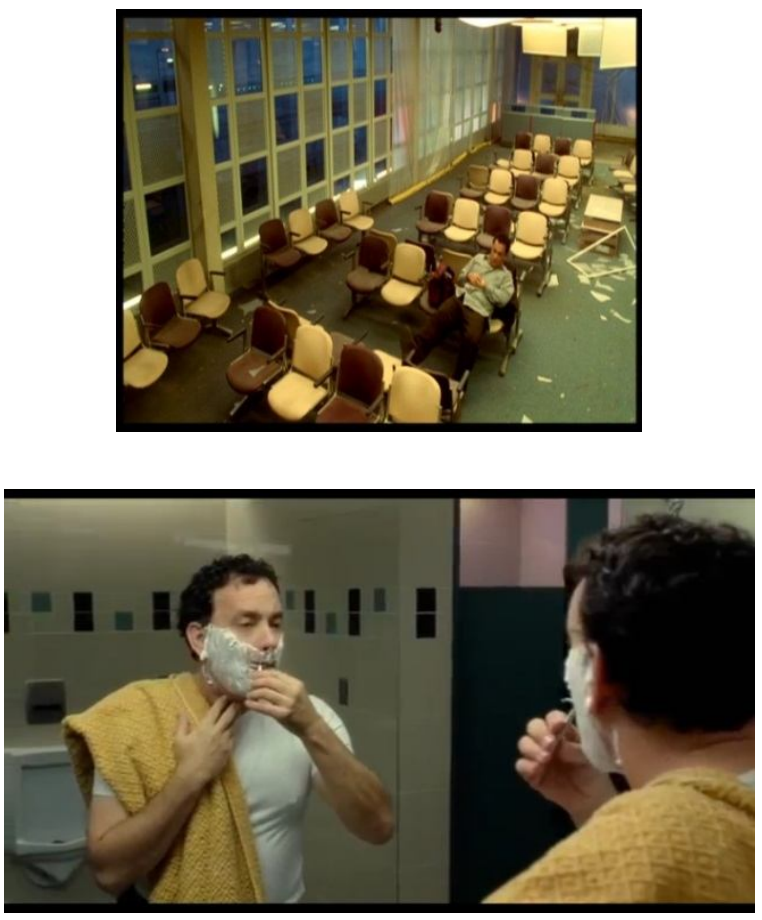

Sayfa/Page | 129

İGÜSBD

Cilt: 3 Sayı: 1

Nisan /

April 2016

\section{Resim 4-5. Kullanıcının kendi özelleștirdiği mekânlar}

Ek Resim:6'de görüldüğü gibi fazla ışık yüzünden uyuyamayınca, bekleme salonundaki sigortaların bir kısmını sökmüş, salonda kendisine çalışma mekânı oluşturmuştur. Tesadüfen terminal içerisinde iş bulmuştur. Hatta bu iş sayesinde iyi para kazanmış. Öyle ki Ek Resim:7'de görüldüğü gibi Terminal binasının içinde dügün bile yapılmıştır.

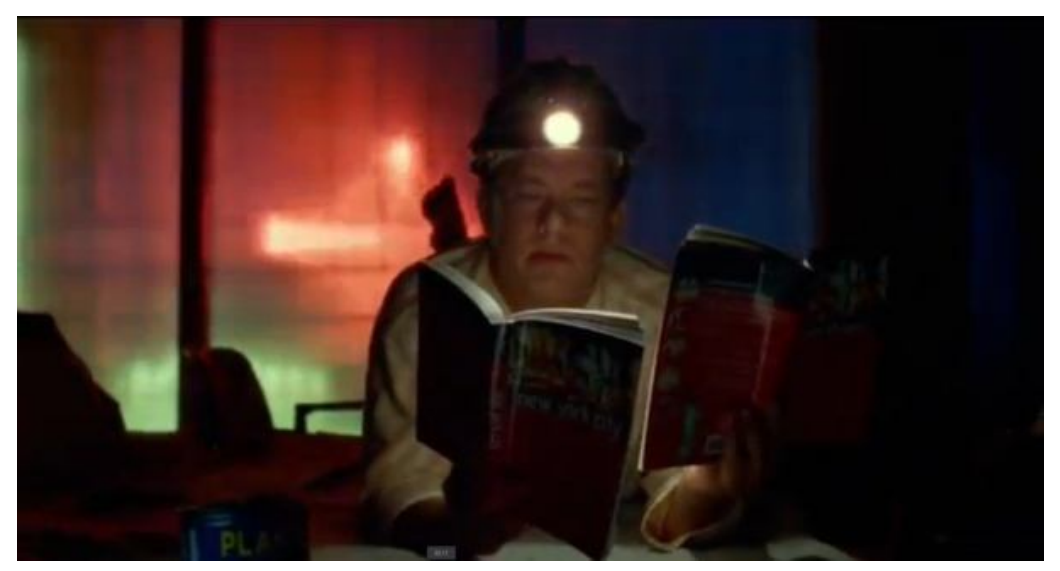

Resim 6. Kullanıcının kitap okumak için kendine mekân oluşturması 
Sayfa/Page | 130 İGÜSBD Cilt: 3 Sayı: 1 Nisan / April 2016

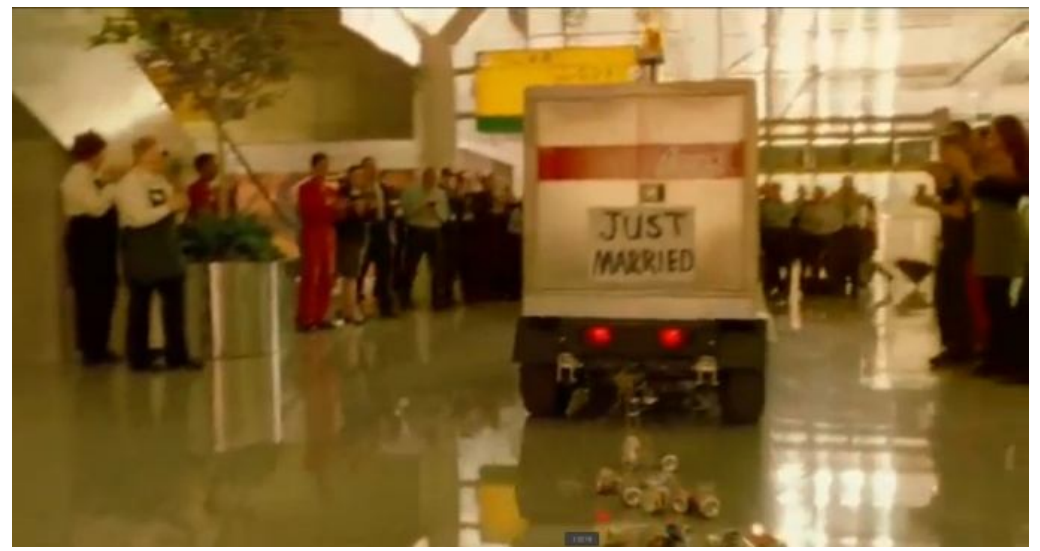

\section{Resim 7. Terminalin işlevinin dışına çıkarak "farklılaşma"sı}

Terminalde terk edilmiş halde veya tamir yapılan yüzeylere etrafta bulduğu malzemelerle kendinden bir şeyler katmış ve kamusal alanda öznelleşen bir yüzey oluşturmuş olduğu gözlemlenmiştir.

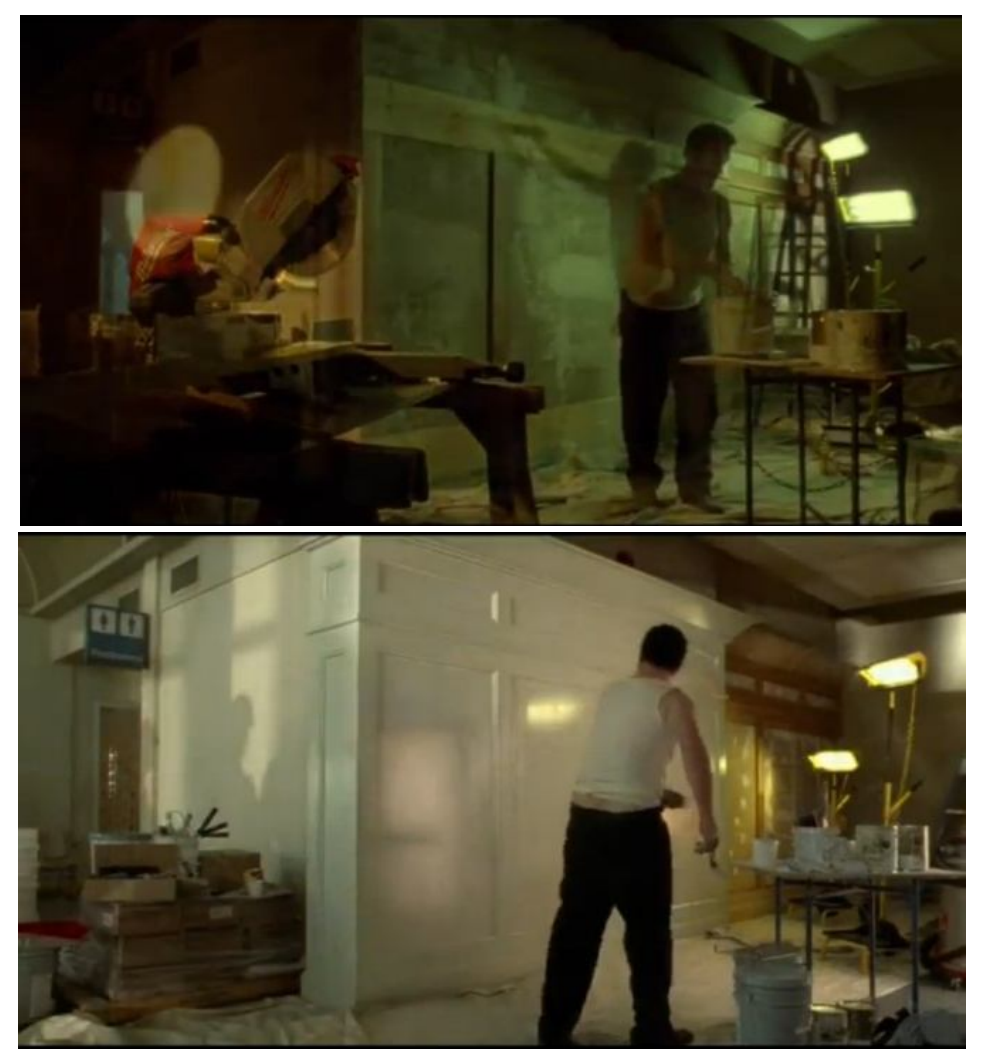

Resim 8-9. Terminal içinde öznelleşen bir yüzey oluşturması 
Ek Resim:10'da görüldüğü gibi Terminalin giriş kapıları (Gate) yolcuların girip-çıkma mekânlarıdır. Oysa kullanıcı bu alanı tam tersi kendi evi haline dönüştürür. Kullanıcı Amerika' ya girmesi yasaklandığı için hapis kaldığı terminal binasını kendi "ev"i haline dönüştürmüştür, terminal'den çlkma izni verildikten sonra karşılaştığı Ek Resim:11'de kent imgesi de terminal'in ilk hali gibi bir yok mekân olduğu gösterilmiştir.

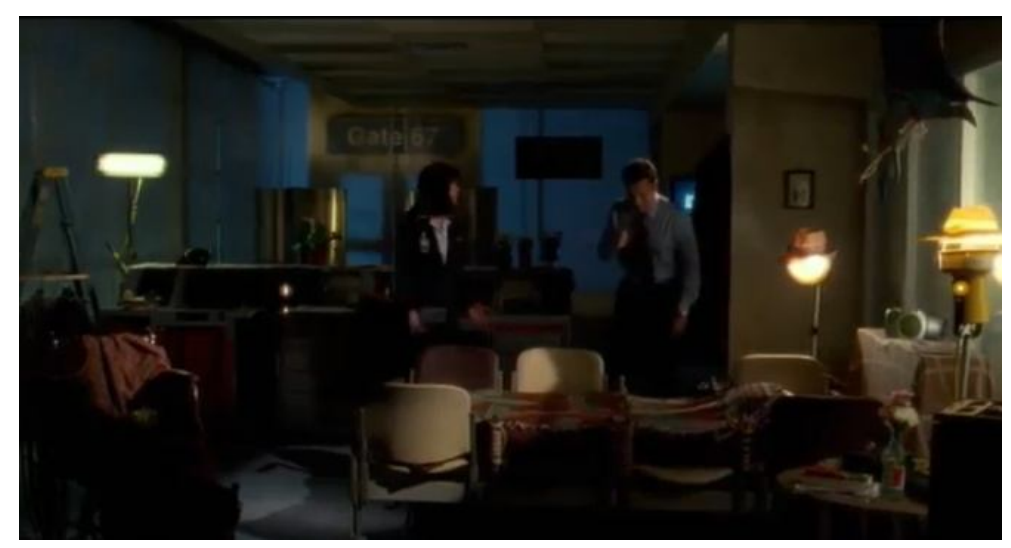

\section{Resim 10. Kullanıcının kendi ve arkadaşına yemek yemek için düzenlediği giriş kapsı}

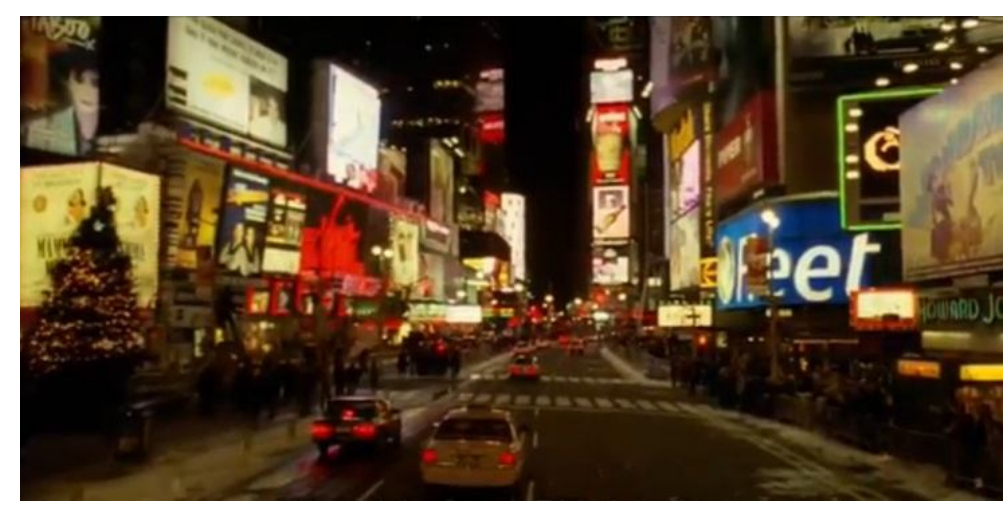

Sayfa/Page | 131

\section{Resim 11. "Yok mekân" olan kent imgesi}

4.2. Gerçek ve hayali mekân zıtlığı kullanılarak yapılan " yok yer" eleştirisi

Mimarlık ve sinemanın en çok etkileşim içinde olduğu bu tür filmlerdir çünkü her ikisi de zaman ve mekân unsurlarını kullanarak yeni bir gerçeklik 
Sayfa/Page | 132 İGÜSBD Cilt: 3 Sayı: 1 Nisan / April 2016 inşa eder. $\mathrm{Bu}$ gerçeklikte genellikle var olan bağlamın manipülasyonu, yerinden edilmesi ya da yeniden üretilmesi yoluyla yapılmıştır.24. Bu üretim biçiminde öne çıkan filmler Tim Burton filmleridir. Baudrillard, imge gerçeklik ilişkisinin Ek Şekil:2' de dört aşamadan geçtiğini söylemektedir. İlk aşamada imge, gerçekliğin bire bir yansımasından ibarettir, ikinci aşamada gerçekliği çarpıtmakta, olduğundan farklı sunmaktadır, üçüncü aşamaya gelindiğinde ise imgenin işlevi görünüm oluşturmak, gerçek diye bir şey olmadığının "gerçeğini" gizlemektir, dördüncü aşamada ise gerçekliğin hiçbir çeşidiyle ilişkisi olmayan, kendi kendine saf simülakrı (Bir gerçeklik olarak algılanmak isteyen görünüm) olan imge vardır. ${ }^{25}$

\section{Şekil 2. İmge-Gerçeklik İlişkisinin Basamakları}

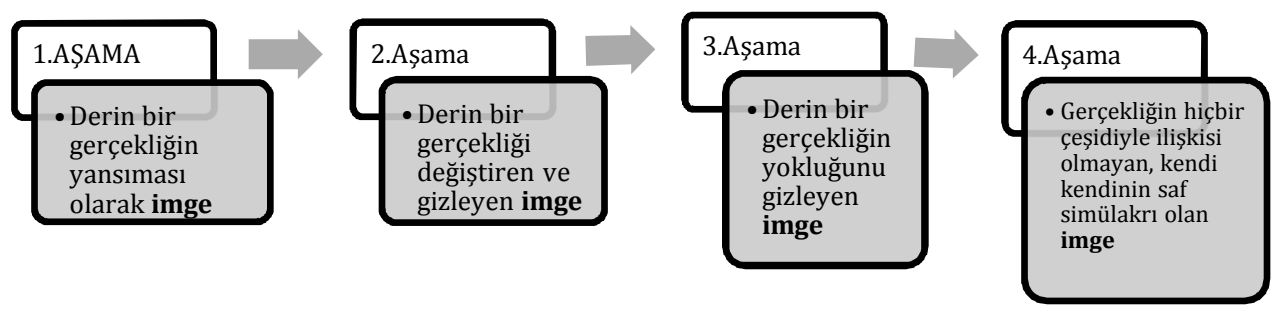

Mekânın imgelerle birleşmesiyle mekân sadece görsel bir ifade olmaktan çıkıp vurgu yapan bir dişavurum ifadesi haline gelmektedir. Mekânsal imgeler mekânda gerçeklikten görselliğe geçiş yapılan bir köprü görevini üstlenmektedirler. Mekânın duyumsattı̆̆ tüm duygu ve düşüncelerin zihinsel mekândaki çevirisidirler.

Bellekteki imgelerin perdedeki görüntüleri tamamlaması ile hissedilir kılınan mekânlar imgelerin zihinde algısal boyutta deneyimlettikleri ölçüsünde anlam kazanmaktadırlar. ${ }^{26}$

Sinema, modern dünyanın hızla iç içe geçen görsel ve işitsel imgelerden oluşan yapısı ve bu yaşamın kentlere getirdiği dinamizm içinde, modern dünyanın insanlarına yeni bakış açıları ve görünmeyeni gösterebilme gücü sunar. Bu bakış açısıyla Tim burton da filmlerinde modern dünyayı ironik bir biçimde ele alan ve alternatif bir dünyanın olabileceğini göstermiştir. "İkilik

${ }^{24}$ Güleç, a.g.m.

25 Jean Baudrillard, Simülakrlar ve Simülasyon, (çev; Oğuz Adanır), Doğu Batı

Yayınlarl, 6.bs., Ankara 1982, s. 20.

${ }^{26}$ Kale, a.g.m. 
merkezli" bu filmlerde modern ve modern olmayan iki farklı dünya, birleşme ya da ayrılma gibi kararsız bir noktada karşı karşıyadır. ${ }^{27}$ Ancak karşıtlıklarına rağmen birbirlerini etkileyip değiștirmeleri nedeniyle aralarında karşılıklılık da bulunmaktadır. Robert Venturi de "mimarlık dediğin karmaşık ve çelişkili olmalıdır"28 derken mimarlığında aynı şekilde dönemden etkilendiğini göstermekte ve kentsel deneyimi parçalı algılı, karmaşık ve çelişkili olarak tanımlar. Yazının bu bölümünün konusu olan Tim Burton, modern dünyanın karmaşıklık ve çelişkilerini yansıtan filmlerinde modern dünyayı ve yer olgusunu bu karşıtlıkla anlatmaya çalışılmıştır. Bu karşıtllğ̆ "her ikisi de-ve" gibi mimari temaları hatırlatacak biçimde modern ve modern olmayan, hatta sürreal olarak nitelendirilebilecek mekânlara filmlerinde birlikte yer vererek yakalamıştır. ${ }^{29}$

Ek Resim:12'da görüldüğü gibi Makas Eller'de renkli ve düzenli banliyö ve karanlık şato; Batman Dönüyor'da Gotham kentinin yerüstü ve yeraltı yerleşimi (Ek Resim:13), Charlie'nin Çikolata Fabrikası'nda rasyonel kent ve fantastik fabrika (Ek Resim:14), Ölü Gelin'de yaşayanların ve ölülerin dünyası (Ek Resim15), Alice Harikalar Diyarında da Londra ve kentin altındaki harikalar diyarı birlikte yer almıştır (Ek Resim16).

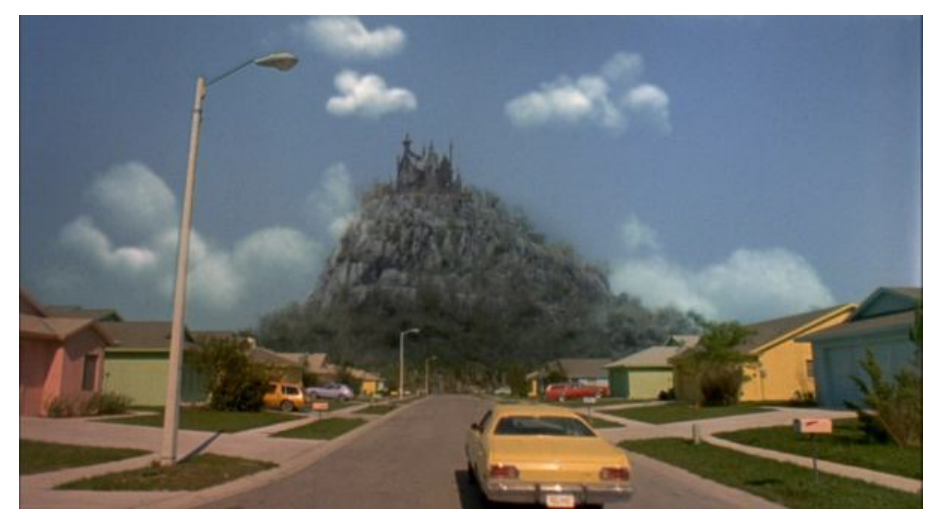

Resim 12. “Makas Eller" banliyö ve karanlık şato karşıtlığı

\footnotetext{
${ }^{27}$ Schuy R. Weishaar, "Tim Burton's Two Worlds", Masters of the Grotesque, The Cinema of Tim Burton, Terry Gilliam, the Coen Brothers and David Lynch, McFarland \& Company Inc., North Carolina, 2012.

${ }^{28}$ Robert Venturi, Complexity and Contradiction in Architecture, The Museum of Modern Art, New York, 2002.

${ }^{29}$ Güleç, a.g.m.
} 
Sayfa/Page | 134 İGÜSBD Cilt: 3 Sayı: 1 Nisan / April 2016

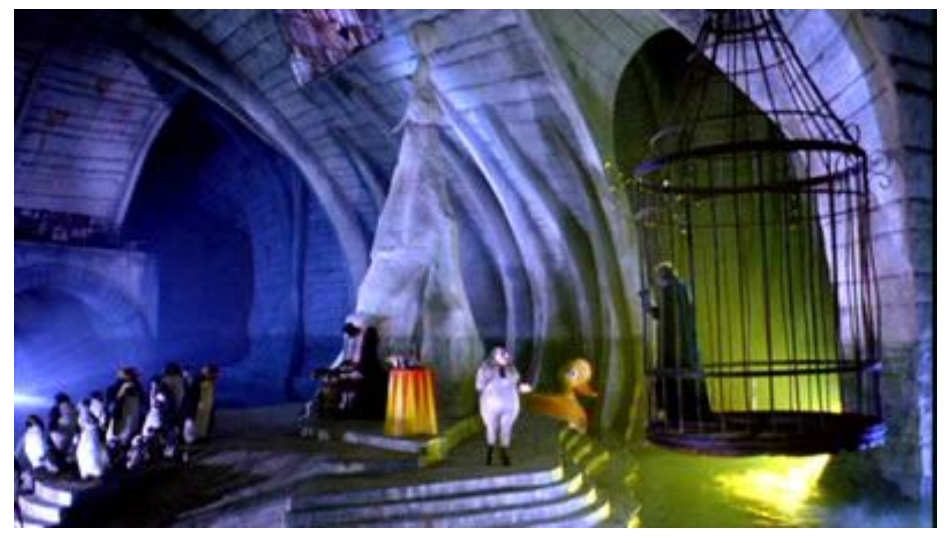

Resim 13. "Batman dönüyor" filmi Gotham kenti

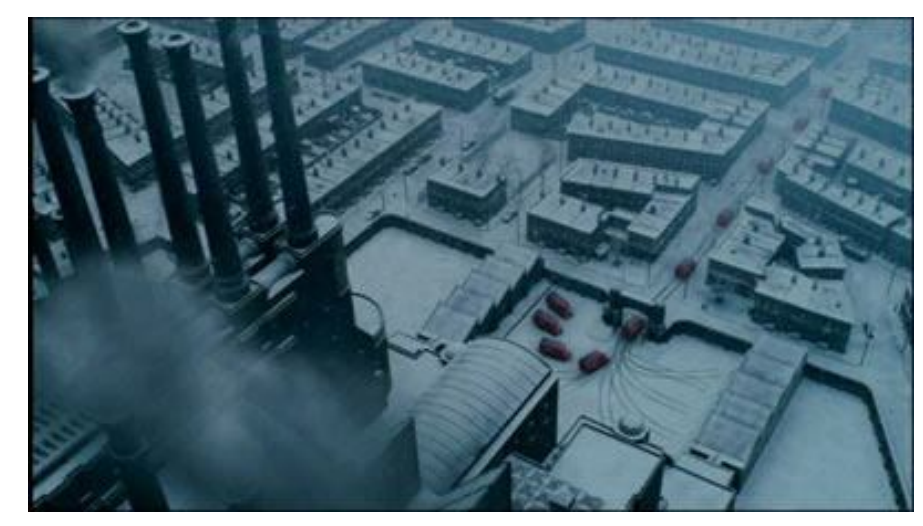

Resim 14. “Charlie'nin Çikolata Fabrikası” rasyonel kent ve fabrika karşıtlı̆̆ı

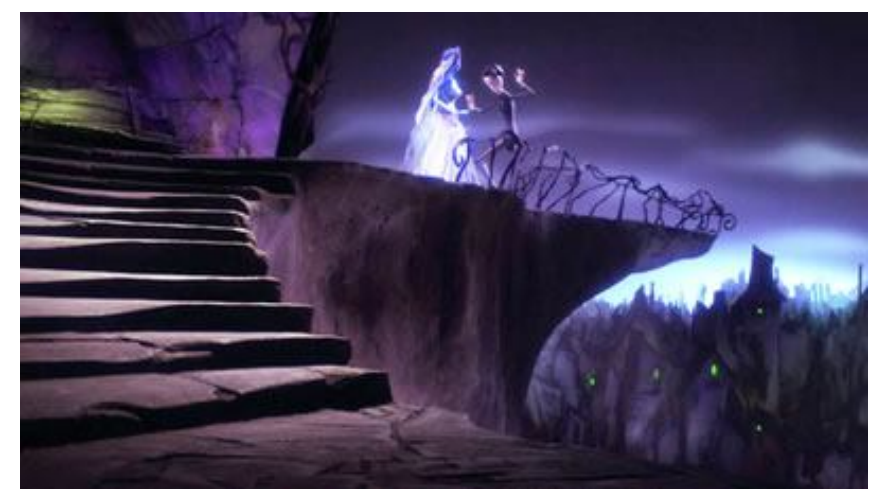

Resim 15. "Ölü Gelin" sürreal mekânları 


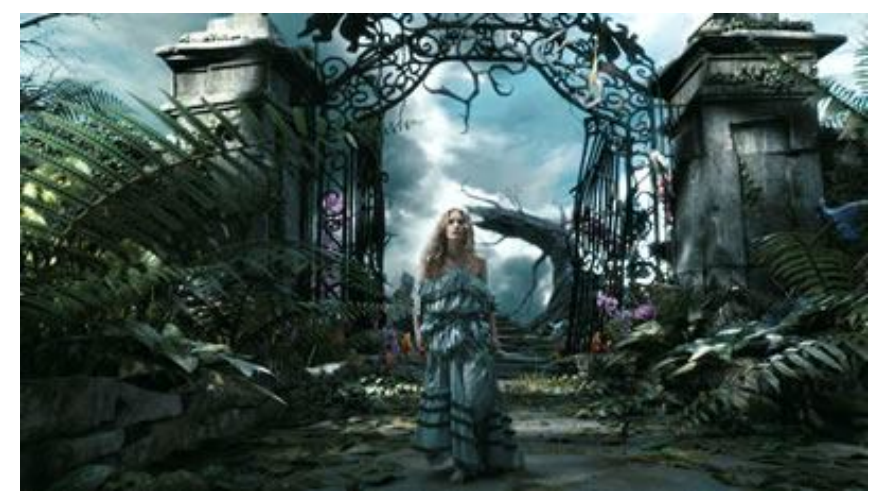

Sayfa/Page | 135

İGÜSBD

Cilt: 3 Sayı: 1

Nisan /

April 2016

\section{Resim 16. "Alice Harikalar Diyarında" Londra ve yer altındaki sürreal mekân}

Modernizmin düzenli, kontrollü mekânlarını ve karakterlerini tasarladığı deforme, itici, tekinsiz mekânları ve karakterleri aracılığıyla eleştirmiştir. Burton filmlerinde modern gelenekselliğin dışında kaldığı görülen öğeler, farklılıkları nedeniyle yabancılaşmaya yol açıyor gibi görünse de bu karşıtlık teması üzerinden bir eleştiri şeklidir. Yönetmenin tanınabilir tarzı, özellikle yer ve zaman tanımı olmayan filmlerinde kendisini göstermektedir. Modernizmin yer ve zaman soyutlamasını eleştirdiği bu filmlerinde kendisi de bilinçli olarak bir "hiçbir yer" ve "hiçbir zaman" kurgusu oluşturmuştur. Makas Eller 'de olayların geçtiği banliyö, belirli bir ritimle tekrarlanan renklere boyanmış detaysız binaları ve aynı renklerdeki otomobilleri ile orta sınıf Amerikan ailesinin yaşadığı yerdir. Neredeyse tüm Amerikan banliyöleri gibi ayırt edici bir topografyası olmayan bu banliyö, sonsuz bir düzlüğe sahip gibidir. Mevsimsel değişimlerin bile olmadığı bu yer, her zaman güneşlidir. Ancak filmde bu gibi mekânsal özellikleri tanımlanmış olan banliyönün yeri ve zamanı tanımsız bırakılmıştır. Filmlerde bu "yok-yer" dediğimiz mekânların bozulabileceği düşüncesi vardır. Ek Resim:17'de görüldüğü gibi Makas Eller'in sonunda Edward'ın banliyönün peyzajını, insanlarını, hatta mevsimini değiștirmesi, Charlie'nin Çikolata Fabrikası'nın sonunda Charlie'nin açgözlülük ve hırsa kapılmayarak fabrikanın varisi olması, babasının ise diş macunu fabrikasındaki işine daha önce yerini alan makineleri tamir etmek için geri dönmesi, Alice Harikalar Diyarında' nın sonunda Alice'in hayal gücü sayesinde toplumsal gelenekleri bozması bu "yok yer" lerin farklılaşma ve üretkenlikle tanımlanıp kimlik kazandırılabileceği düşüncesi olduğu gösterilmiştir. 
Burton, banliyönün tarih ya da kültür bilinci olmayan bir yer olduğu için bir tür muğlaklık ve boşluk tanımladığına inanmaktadır. Bu bakış açısına göre banliyö, yok-yer olarak adlandırılabilir, çünkü yok-yerlerde coğrafik ya da topografik belirleyiciler bulunmamakta, anılardan ya da tarihsellikten söz edilememektedir. Bu nedenle Makas Eller'deki banliyö, Burton' a göre

Sayfa/Page | 136 İGÜSBD herhangi bir yer ve zamanda yaşanabilecek olayları aktarmak için doğru bir seçim olmuştur. Filmlerindeki yok-yerler aracıllğıyla Burton, modernizmin "yerin ruhu"nun (genius loci) kaybolmasına yol açtığını göstermektedir. ${ }^{30}$

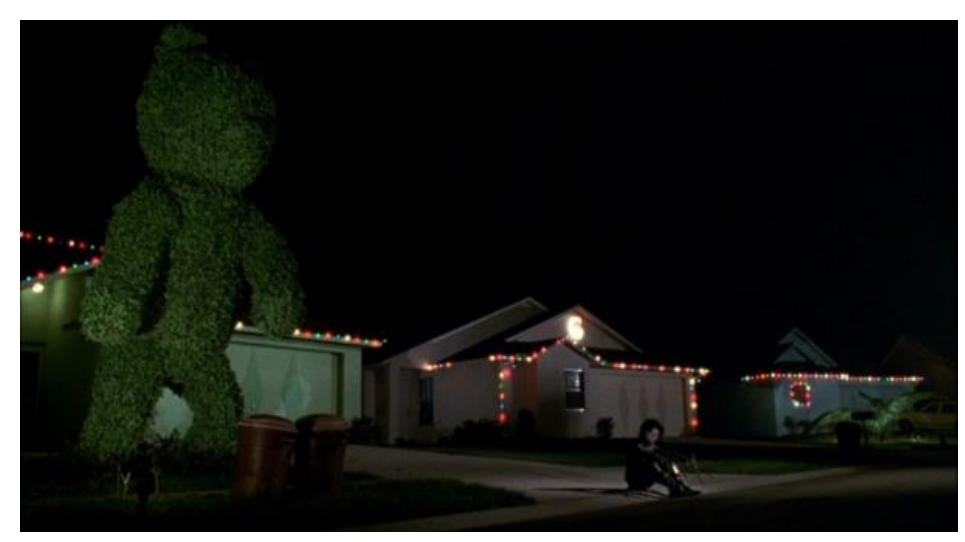

\section{Resim 17. "Makas Eller" de Edward'ın düzenli banliyö kentine kattığı "farklılık"lar}

Modernizm, 20. yüzyll itibariyle tüm kültürleri içine alacak kadar genişleyip anlamını yitirmeye başlamıştır. Tim Burton da bu tür filmlerinde farklı zamanlara ve yerlere ait detayları bir araya getirerek bir tür kolaj oluşturmaktadır. Ancak kolaj, mimarlıkta şekil-zemin, ütopya-anti ütopya, geçmiş-gelecek gibi karşıtlıkların uyumlu bir kentsel bütün oluşturabileceğini göstermek için kullanılmışken Burton filmlerinde aksine bir bütünlük oluşturmayan uyuşmazlıklar vurgulanmıştır. ${ }^{31}$

Ek Resim:18'de gösterildiği gibi Burton, mekân ve karakter uyuşmazlıklarını oluşturan mekânsal ve bedensel detayları birer sembol olarak kullanmaktadır. Mimarlıkta da anlamın semboller üzerinden kurulması yaygın ve meşru bir yaklaşımdır. Burton'ın makaslara yüklediği anlam - basit

30 Güleç, a.g.m.

31 Jenny He, "An Auteur for All Ages", Tim Burton, The Museum of Modern Art, New York, 2009. 
ve karmaşık, üretici ve yıkıcı- filmlerinde modern dünya ile eş zamanlı olarak yer alan sürreal dünyanın doğasını anlatmaktadır.

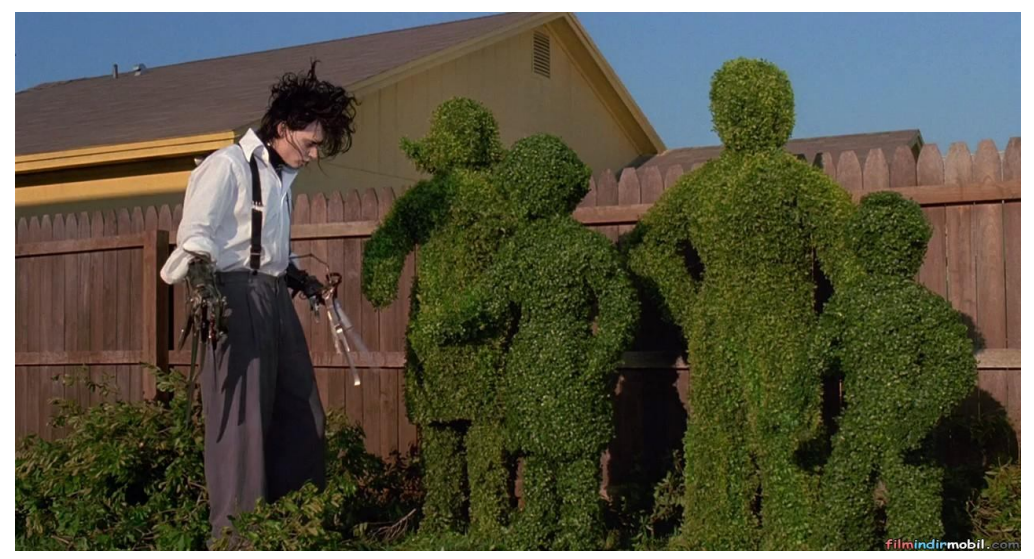

\section{Resim 18. "Makas Eller" de Edward'ın deforme bedeni(makaslar) ve modern giysilerinin karşıtlığı}

\subsection{Dolaylı olarak mekân ve olay kurgusu kullanılarak yapılan "yok yer" eleştirisi}

Lefevbre' ye göre mimarlık mekânı oluşturan bir araçtır ve mekân oluşumunda insan ilişkileri ve kapitalist üretim süreçlerinin etkileri vardır. ${ }^{32}$ Kapitalist toplumlarda mekân, insan ve toplum ilişkilerinin düzenlenmesini sağlayan bir araca dönüşür. Böylece "yer", mekânın coğrafi ve fiziksel özelliklerinin ötesinde kapitalist sistemin bir ürünü olarak karşımıza çıkar. Marjinalliği Tim burton filmlerinde fantastik kurgulama olarak ele almışken bu bölümde ise sistem dışı eylem ve ilişkiler etkileriyle yeniden tariflendiğini düşünebiliriz. Suç ve yer altı dünyası, alternatif üretim süreçlerinin içinde yer almasından dolayı sinemaya malzeme sağlar. Yönetmenin vermek istediği şiddet ve sıra dışıllğın dozu seyirci için kasıtll olarak bir doz üstte tutulmuştur. ${ }^{33} \mathrm{Bu}$ özellikler dikkate alınarak bu bölümde "Dövüş Kulübü" filminin mekânları incelenmiştir. Film mekânları gerçek mekânlardan oluşmaktadır. Bu filmde öznelerin etkileriyle mekân gelişimi değişmektedir ve kapitalizmin etkisiyle ortaya çıkan kent mekânları analiz edilmiştir. Bir grup kayıp bireyin, kente ve birbirinin aynı marka bağımlısı kent insanına, mevcut sisteme ve iktidara anarşist bir karşı çıkış; alternatif bir toplum ve yer arayışını anlatır. 20.yy'da kent adeta bir reklam panosuna dönüşmüş, simgesel

\footnotetext{
${ }^{32}$ Henri Lefebvre, The Production of Space, (Oxford: Blackwell, 1991), 287.

33 Seçkin Kutucu, "Sinemada Marjinallik ve Mekân”, Ege Mimarlık, sayı:45, 2003, s.26.
} 
yapılarla çevrilmiş, insana dair "kimlik", "farklılık" ve "mahremiyet" unsuru barındırmadan makineleştiği düşünülüyordu. Bu da tüm kentin bir "yok yer" olarak tanımlanmasına sebep olmuştur. Kişinin ise öznelliğini kentin insanları prototipleştirdiği düşünülen yapılarına zarar vererek kanıtladığı düşünülmüştür. Bu şekilde insanların özgür kılınabileceğini düşünülmüştür.

Sayfa/Page | 138 İGÜSBD Cilt: 3 Sayı: 1 Nisan / April 2016

Ek Resim:21-22 ve 23'de gösterilen hava alanları, iş ve alış veriş merkezleri, çok katlı firma binaları, oteller kişinin kendine ait hissedemediği sadece belirli bir amaç ve ihtiyaç için kullandığı, sistemin "yok-yer" olarak adlandırılmasına sebep olan, kimliğe ve öznelliğe zarar veren yapıları olduğu için hedef olarak seçilmiştir. Ancak filmde kişinin kendi evi bile marka eşyalardan oluşan bir "kimlik" unsuru barındırmayan mekânlara dönüşmüştür. Kişi de zarar vermeye önce evinden başlar. Tüm bu kurgunun planlandığı mekânlar, yer altı, boş ve köhne yine bir yer özelliği olmayan mekânlardır. Kentin tüm hızına karşıtlık yaratmak için, durağan mekânlar izleyiciye aktarmak istenen amaç doğrultusunda seçilmiştir. Burada kişi kimliğini, "yok yer" olarak belirlenen bu mekânlara yine bir "farklılık" kazandırarak tanımlamıștır. Terminal filminde özne bu mekânları kendine ait bir yere dönüştürmeye çalışırken bu bölümde incelenen film türünde ise bu mekânlar tepki olarak yok edilmeye çalışılmıştır.

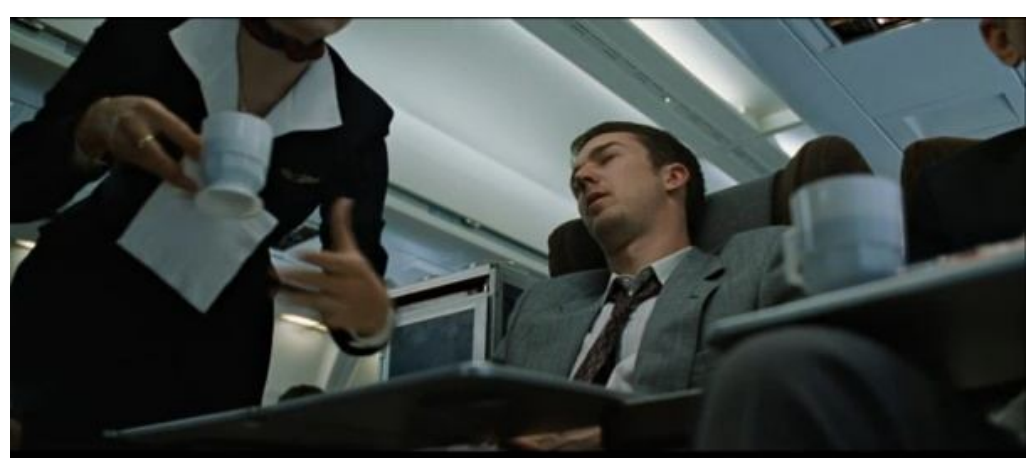

Resim 19. Kişinin ulaşım için kullandığı mekânları 


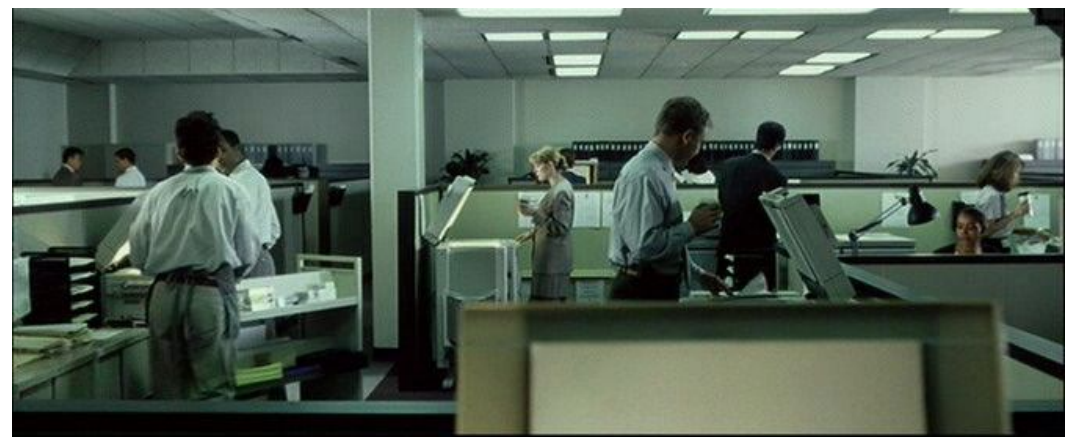

Sayfa/Page | 139

İGÜSBD

Cilt: 3 Sayı: 1

Nisan /

April 2016

Resim 20. Yok-yer olarak adlandırılan tek tip ofis binaları

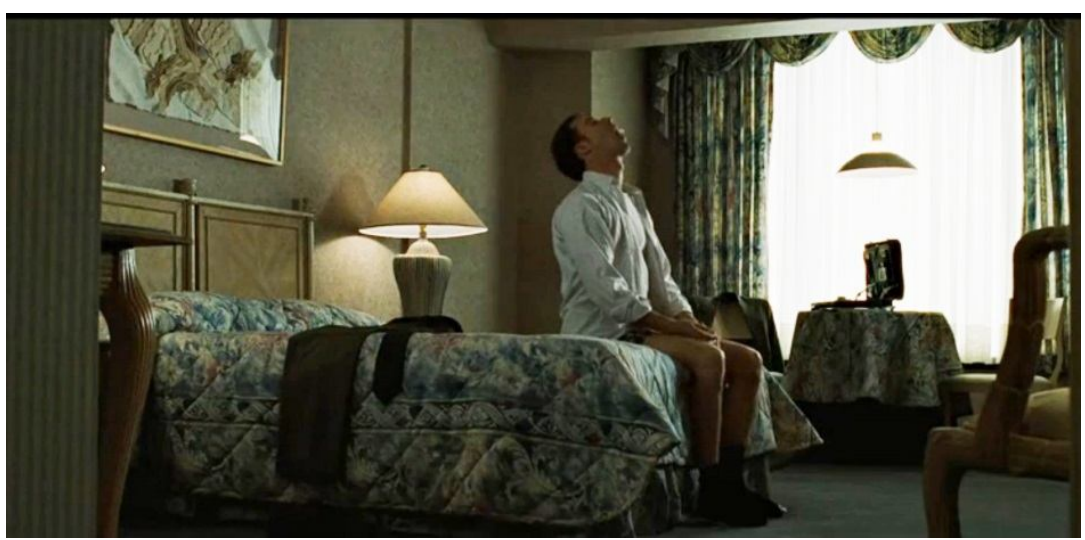

Resim 21. Yok-yer olarak tanımlanan geçici konaklamalar-oteller

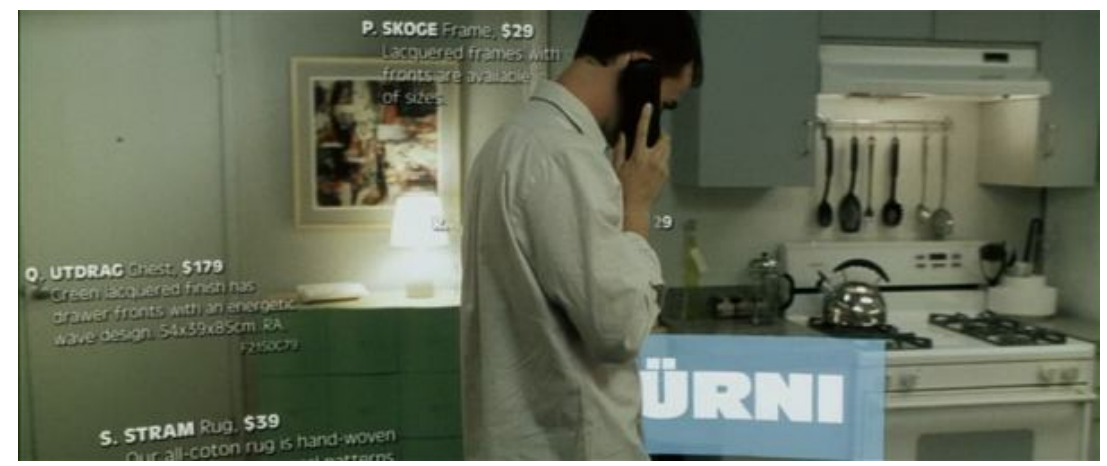

Resim 22. Marka eşyalarla doldurulmuş kimliksiz ev 
Sayfa/Page | 140 İGÜSBD Cilt: 3 Sayı: 1 Nisan / April 2016

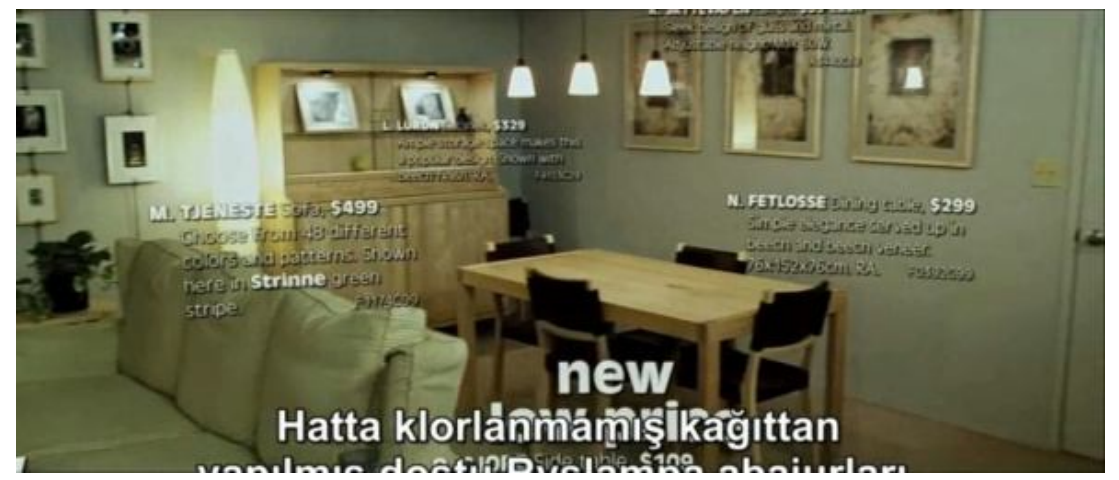

\section{Resim 23. Marka eşyalarla doldurulmuş kimliksiz ev}

Modernin tanımsız mekân olarak adlandırılan "yok-yer"leri markalaşmış ve kişilere yabancılaşmıș, yoğun kalabalığa ve aşırı ışıklı mekânlarına karşıtlık bağlamında Ek Resim:24, 25 ve 26'da görüldüğü gibi toplumdan sıyrılan "kayıp" olarak nitelendirdiğimiz bireylerin, yaşamayı seçtikleri ve eylemlerini planladıkları yer karanlık boş ve köhne alternatiflerdir. Ancak bireyler bu boş ve köhne yapılara karakter kazandırarak mekân duygusu olan bir yere dönüştürmektedir. 34

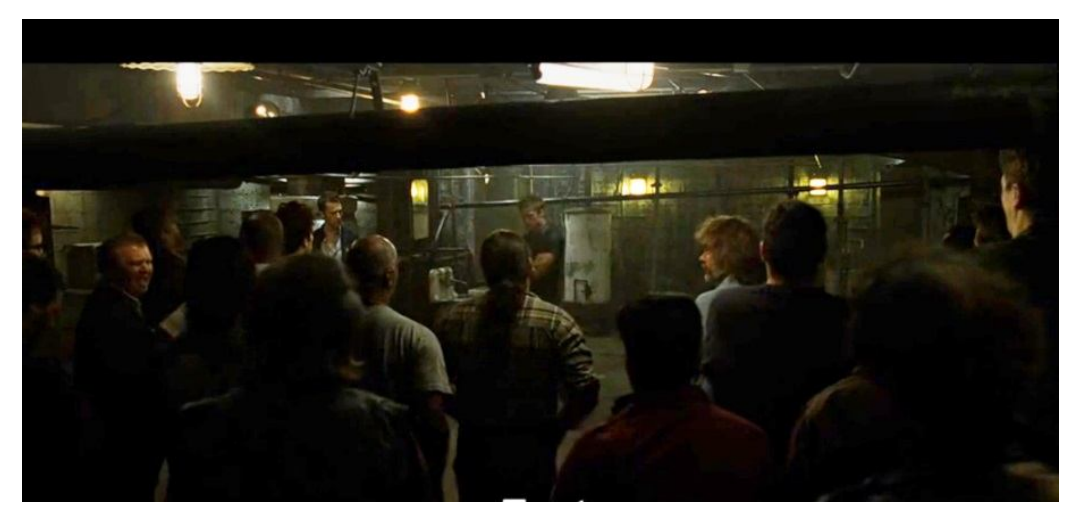

Resim 24. Boş, köhne alternatif mekânlar

34 Kutucu, a.g.m. 


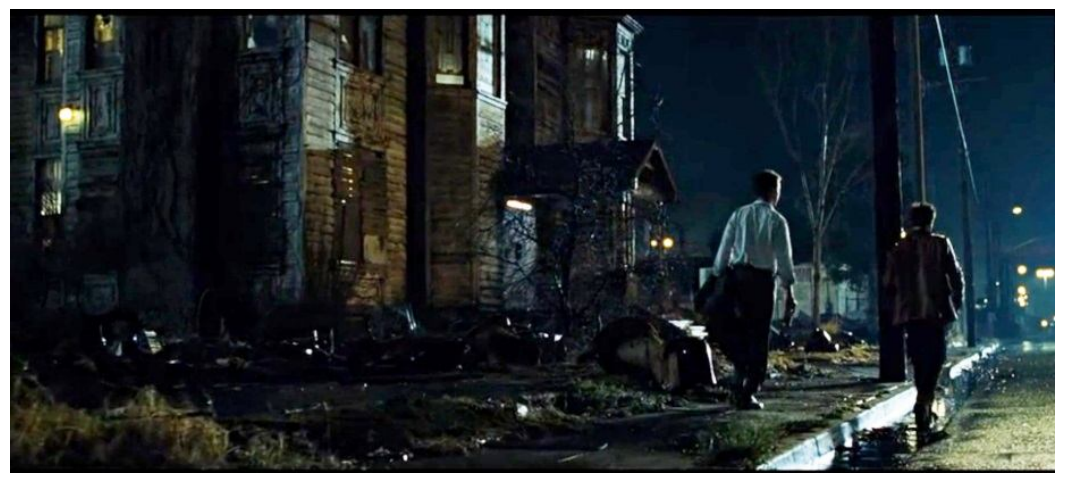

Sayfa/Page | 141

Resim 25. Bireyin seçtiği yeni "ev" imgesi

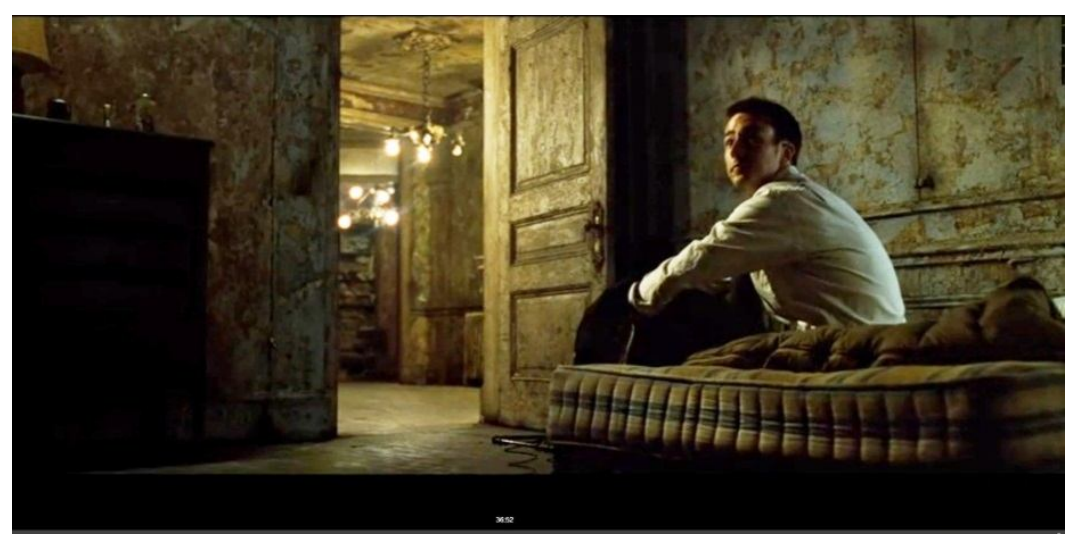

Resim 26. Bireyin markadan arındırılmış, bakımsız ve terk edilmiş yeni yaşam yeri

Ek Resim:26'da gösterildiği gibi bireyin, zamanın getirdiği "yabancılaşma" ve "monotonlaşma"ya karşı ilk tepkisi kendi evini yakmak olmuştur. Bu kurgu, mimarinin birey üzerindeki önemini vurgular. Ardından planlarına devam eden kayıp bireyler, kentin tanımsız mekân olarak adlandırılan çok katlı ofis binaları, otel gibi "yok yer"lerini hedef olarak seçer. Ek Resim:27'de gösterilen bu yok etme girişimiyle birlikte bireyin kendin kimliğini geri kazandığı "imge"si seyirciye verilmek istenmiştir. Kentteki "yok-yer"leri “yok etmek" kullanıcı özgür kılmıştır. 


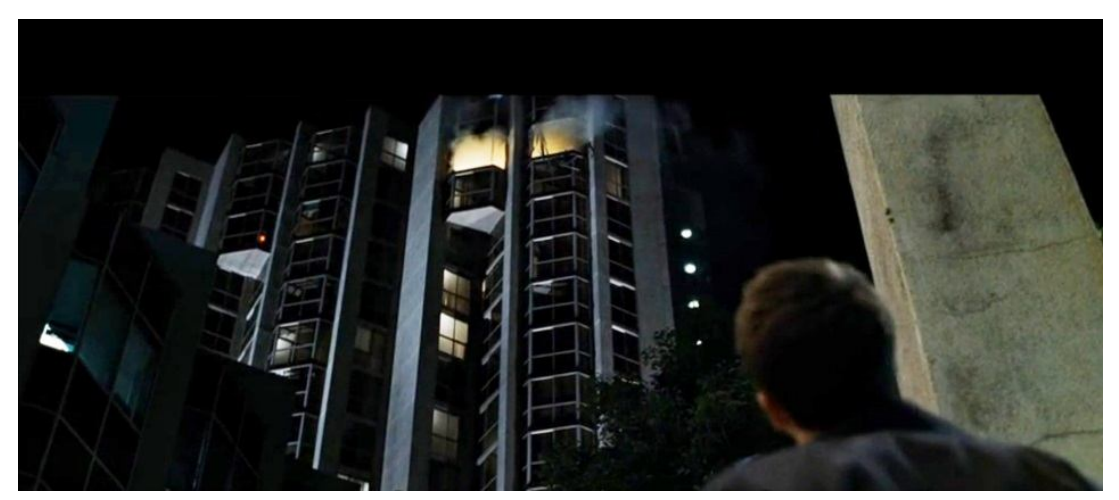

Şekil 26. Bireyin evini yaktığı imge

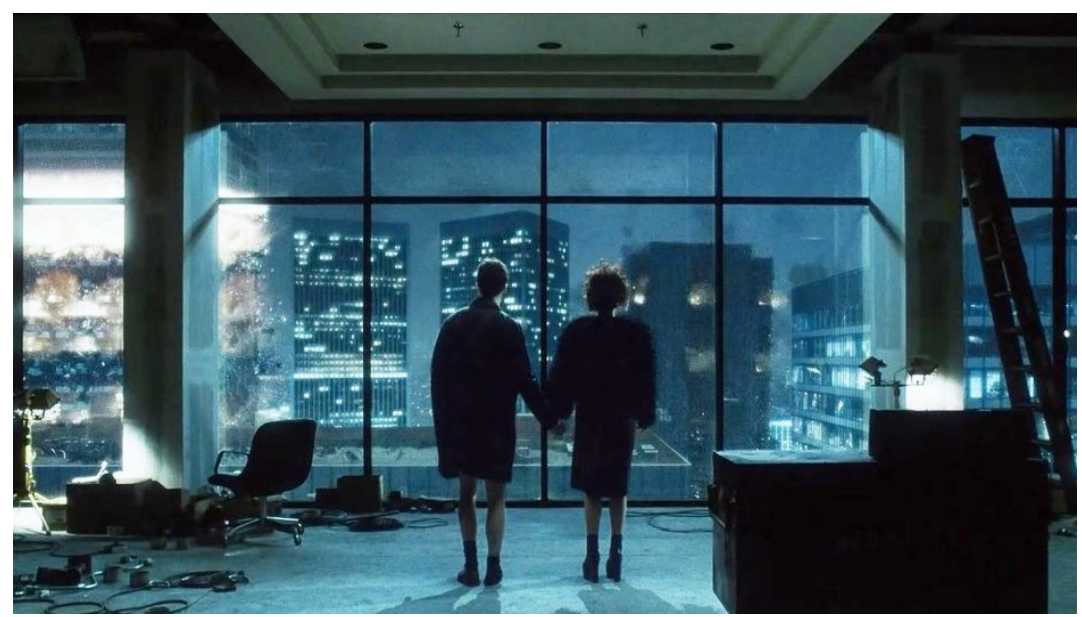

Şekil 27. Bireyin kentin yok-yerlerini patlattığı imge 
5. Sonuç ve Değerlendirme

\begin{tabular}{|c|c|c|}
\hline FILM GRUPLARI & $\begin{array}{l}\text { MEKÂNIN ÜRETIMM } \\
\text { BİÇIMII }\end{array}$ & $\begin{array}{l}\text { MEKÂNIN KULLANIM } \\
\text { BİÇIMİ }\end{array}$ \\
\hline 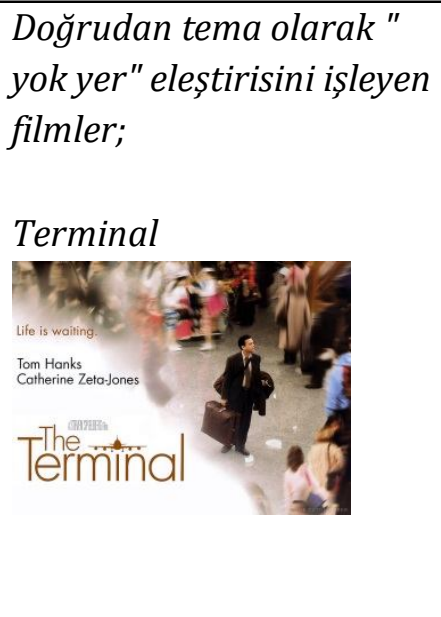 & $\begin{array}{l}\text { Sinema mekânları, } \\
\text { mevcut ve gerçek } \\
\text { mekânlardan } \\
\text { üretilmiştir. "Yok-yer" } \\
\text { kavramı doğrudan bu } \\
\text { kavramın } \\
\text { temsilcilerinden biri } \\
\text { olan terminal binasında } \\
\text { geçmektedir. }\end{array}$ & $\begin{array}{l}\text { "Yok-yer" olarak } \\
\text { adlandırılan Terminal } \\
\text { yapısının insan faktörü } \\
\text { ve deneyimiyle } \\
\text { mevcut mekânın bir } \\
\text { yer e dönüşümünü } \\
\text { temsil eden farklı } \\
\text { mekânsallaşmalar } \\
\text { karelerin } \\
\text { dondurulmasıyla } \\
\text { yöntemiyle } \\
\text { gösterilmiştir. }\end{array}$ \\
\hline $\begin{array}{l}\text { Doğrudan mekân ve olay } \\
\text { kurgusu kullanılarak } \\
\text { yapılan "yok yer" eleştirisi; } \\
\text { Dövüş Klubü }\end{array}$ & $\begin{array}{l}\text { Sinema mekânları, } \\
\text { mevcut ve gerçek } \\
\text { mekânlardan } \\
\text { üretilmiştir. Hava } \\
\text { alanları, iş ve alışveriş } \\
\text { merkezleri, çok katlı } \\
\text { firma binaları ve diğer } \\
\text { ticari yapılar birebir } \\
\text { modern dünyada } \\
\text { üretilen "yok yer"ler } \\
\text { olarak adlandırılmıştır. }\end{array}$ & $\begin{array}{l}\text { Mevcut "yok-yer" lerin } \\
\text { yine insan faktörü ve } \\
\text { deneyimiyle içinde } \\
\text { bulundukları çevreyi } \\
\text { yeniden şekillendirme } \\
\text { düşüncesiyle bir oyun } \\
\text { içinde yok edilmesi ve } \\
\text { kendilerine yer olarak } \\
\text { seçtikleri boş ve köhne } \\
\text { yapılara yer ve } \\
\text { karakter duygusu } \\
\text { yüklemeleri temsili } \\
\text { mekanlarla karelerin } \\
\text { dondurulmasıly } \\
\text { yöntemiyle } \\
\text { gösterilmiştir. }\end{array}$ \\
\hline
\end{tabular}

Sayfa/Page | 143

İGÜSBD

Cilt: 3 Sayı: 1

Nisan /

April 2016 
Sayfa/Page | 144 İGÜSBD Cilt: 3 Sayı: 1 Nisan / April 2016
Gerçek ve hayali mekân
zıtlığı kullanılarak yapılan
"yokyer" eleştirisi;

\section{TIM BURTON FILMLERI}

(Makas Eller, Charlie'nin

Çikolata Fabrikası, Alice

Harikalar Diyarında, Ölü

gelin, Batman dönüyor)

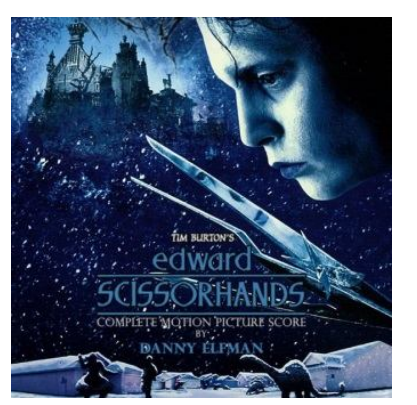

Sinema mekânları, gerçek mekânlardan ve "İnşaedilmemiş" (unbuilt) ve gerçekte var olmayan sanal mimari mekânlardan üretilmiştir. Ancak "yok-yer" eleştirisini temelde anlatan temsili mekânlar, gerçek ve ya sanal olması fark etmeksizin modern kentler/bölgeler ve bunlara alternatif olarak üretilmiş sürreral kentler / bölgeler birlikte kullanılmıștır.

Makas Eller'de renkli,
düzenli ve minimal
banliyö yerleşimi ve
karanlık ve çarpıcı şato;
Batman Dönüyor'da
Gotham kentinin
yerüstü ve yeraltı
yerleşimi; Charlie'nin
Çikolata Fabrikası'nda
rasyonel kent ve
fantastik fabrika; Ölü
Gelin'de yaşayanların
ve ölülerin dünyası;
Alice Harikalar
Diyarında'da Londra ve
kentin altındaki
harikalar diyarı birlikte
yer almıştır.

Tablo 2. Seçilen filmlerin analiz yöntemine göre değerlendirilmesi

Modern yaşam kültürüne eleştirel yaklaşan 3 ayrı film üzerinden, sinema mekân kurgusunda "yok yer" eleştirilerinin temsilleri incelenmiștir. İncelenen üç ayrı film türünde de 20. Yüzyıl modernizminin, sıradan kentler ve bu sıradan kentlerin çağa özgü havaalanı, otoban, süpermarket, alışveriş merkezi, otel odası gibi mekân tipolojileri ve hatta sıradan bireyler oluşturduğu düşünülmektedir. Terminal ve Dövüş Kulübü filminde mekân ve karakterler "gerçek" yaşamdan seçilirken, Burton'ın filmlerinde ise gerçekte olmayan hayal ürünü, sıra dışı mekânlar ve insanlar kurguladığı görülmüştür. Filmlerindeki sıra dışı karakterlerin bozulmuş bedenleri ve yaşadıkları karanlık mekânlar, hem modernin günlük yaşantısının aksinde hemde beraberinde olan yeni bir gerçeklik inşa etmiştir. Burton'ın "yer"i ve "zaman" tanımsız bıraktığı filmlerinde "yer"i bağlamsızlaştırdığı bir gerçekliktir. ${ }^{35}$ Terminal ve Dövüş Klubü filmlerinde modernin simgesi sayılan "yok-yer" lere vurgu yapılır ve bu yerlerin insan faktörü deneyimi ile fiziksel ve psikolojik dönüşümüne tanık oluruz. Tim Burton'ın filmlerinde ise karakterler ve

35 Güleç, a.g.m. 
mekânlar ikilidir. Örneğin; Makas Eller'de renkli, düzenli ve minimal banliyö yerleşimi ve karanlık ve çarpıcı şato ile banliyö halkına karşılık gelen deforme olmuş bedeniyle karanlık şatonun ve makas eller isminin sahibi Edward karakteri, Batman Dönüyor'da Gotham kentinin yerüstü ve yeraltı yerleşimi; Charlie'nin Çikolata Fabrikası'nda rasyonel kent ve fantastik fabrika; Ölü Gelin'de yaşayanların ve ölülerin dünyası; Alice Harikalar Diyarında'da Londra ve kentin altındaki harikalar diyarı birlikte yer almıştır. Bu değerlendirmede Burton'ın filmlerini diğer örneklerden ayıran temel özellik bu birbirine alternatif olan mekanların karşılıklı olarak birarada kullanılmalarıdır.

Terminal filminde günümüz modernin gerçek "Yok- yer" mekanlarından olan Terminal binasına ana karakterin o mekana kimlik kazandırması sonucu o mekanı bir "yer"e dönüştürdüğü görülmektedir. Aynı şekilde Tim Burton'ın Modernizmin yer ve zaman soyutlamasını eleștirdiği Makas eller filminde kendisi de bilinçli olarak bir "hiçbir yer" (no-place) ve "hiçbir zaman" (no-time) kurgusu oluşturmuştur. "Makas eller" de iki farklı banliyönün peyzajını, insanlarını, hatta mevsimini değiștirmesiyle banliyöye yine bir "kimlik" tanımlamasıyla pozitif etkisi görülmektedir. Aynı şekilde Alice Harikalar Diyarında'nın sonunda Alice'in hayal gücü sayesinde toplumsal gelenekleri bozması da buna örnek gösterilebilir. Dövüş Kulübünde ise filmin sonunda tüm "yok yer"ler patlatılmış ancak kahraman kimliğini geri kazanmıştır. Terminal filminde kahraman her ne kadar sonunda terminalden çıkmış olsa da filmin sonunda reklam panolarıyla dolu kentin içinden geçerek "evim" (yuva) diye tanımladığı yere yani başta "yok yer" olarak adlandırdığımız terminale geri döner.

Burada değinilen filmlerde kendi içindek farklı mekân üretme ve mekânı kullanma şekilleriyle modernizme yer bağlamında eleştirileri söz konusudur. modernizmin genelleştirme yaklaşımının standardizasyon ve prototipleşmeye yol açtığına, makineleşme ile birlikte bireysel beceri ve yaratıcılıkların yok olduğuna dikkat çekilmiştir. Oysa gerçek modern yaşam kültürü, gündelik yaşamın ritmini borçlu olduğu rastlantısallıkları ve gerilimleri barındırmalıdır. Ancak böyle bir kültürün kentler, mekânlar ve insanlara canlılık ve hareket getireceğini gösterilmektedir. Burton'ın da gösterdiği gibi varolan dünyanın her zaman bir alternatifi olabilir. Alternatif sinemasal ve mimari tasarım göstermektedir ki; kentsel düzenden yaşam kültürüne dek her şeyin sürekli olarak değiștiği bugünün ortamında yaşamda dinamik bir bağlamın kurgulanması ve kurulmasından geçmekte olduğu gösterilmiştir.

Sayfa/Page | 145

İGÜSBD

Cilt: 3 Sayı: 1

Nisan /

April 2016 


\section{KAYNAKÇA}

ANDERSON, Perry, Postmodernitenin Kökenleri, (çev. Elçin Gen), İstanbul: İletişim Yayınları, 2005.

BALA, Havva, "Reading of the Architectural Identity Via Cinema", Cinej Cinema Journal, sayl: 4.1 no: 81, 2014.

BALA, Havva, "Sinemada Mimari Okumaları", 2014, http://saklisinema. com/index.php/2014/10/16/sinemada-mimari-okumalar/ (Erişim Tarihi 31.12.2014).

BALA, Havva, "Mimarlıkta yok yer kavramı ve Terminal" , 2014, http://www.boyutpedia.com/1613/69627/mimarlikta-\%E2\%80\%9Cnonlieu\%E2\%80\%9D-kavrami-ve-terminal (Erişim Tarihi:04.01.2015).

BAUDRILLARD, Jean, Simülakrlar ve Simülasyon, 6.bs., Ankara: Doğu Batı Yayınları, 1982.

BOXER, Lionel. "Assessment of Quality Systems with Positioning Theory", The Self and Others: Positioning Individuals and Groups in Personal, Political and Cultural Contexts, (Ed. R.Harré ve F. Moghaddam), Westport: Praeger Publishers, 2003, ss. 251-277.

CEYHUN, D., "Modern Kavramı ve Mimarlık", Yapı Dergisi, 248, 2002, ss. 54-57.

COURBUSIER, Le, Bir MimarlığaDoğru, Yapı Kredi Yayınları, İstanbul, 2015.

DELEUZE, Gilles, Guattari, Felix, A Thousand Plateaux: Capitalism and Schizophrenia, London: Athlone Press, 1987.

DORSAY, Atilla, "Mimarlık Hayatlarımızı Somut Olarak Biçimleyen Bir Sanat...", 2013, www.yapi.com.tr (Erişim Tarihi: 31.12.2014).

EROĞLU, Belkıs, "Hayalle Hakikat Arasında Bir Yerde", 2011, http:// www.hayalperdesi.net/dosya/85-hayalle-hakikat-arasinda-bir-yerde.aspx (Erişim Tarihi: 02.01.2014).

GÜLEÇ, Gülşah, "Modernizm Eleștirileri”, 2013, http://www.mimarlik dergisi.com/index.cfm?sayfa=mimarlik\&DergiSayi=389\&RecID=3303 (Erişim Tarihi: 31.12.2014).

HEIDEGGER, Martin. Poetry, Language, Thought, (çev: Albert Hofstadter), New York: Harper \& Row, 1971.

HE, Jenny, "An Auteur for All Ages", Tim Burton, The Museum of Modern Art, New York, 2009.

HENRI, Lefebvre, The Production of Space, Oxford: Blackwell, 1991.

KALE, Gül, “Antonioni'den Godard'a Filmlerdeki Mekân İmgelerinin Duyumsattıkları", Arredamento Mimarlı, sayı: 169, 2004. 
KOCA, K. Senem," Çağdaş Mimarlıkta Yersizlik", İ.T.Ü. Fen Bilimleri

Enstitüsü, İstanbul, 2005 (Yüksek Lisans Tezi).

KUTUCU, Seçkin, "Sinemada Marjinallik ve Mekân”, Ege Mimarlık, sayı: 45, 2003.

MALPAS, Jeff, Place and Experience: A Philosophical Topography, Cambridge: Cambridge University Press, 1999.

NORBERG-SCHULZ, Christian, Genius Loci, Academy Editions, Londra, 1980.

PAȘAOĞLU, Ali, "Sinema ve Mimarlık: İki Düșünen İmalât", 2011, http://www.hayalperdesi.net/dosya/84-sinema-ve-mimarlik-iki-dusunenimalat.aspx (Erişim Tarihi: 31.12.2014).

RATTENBURY, K., Echo and Narcissus, in Architecture \& Film, Ed. M. Toy, Architectural Design Profile 112, vol. 64 (12), 1994, ss. 7-35.

SENNETT, Richard. Gözün Vicdanı, Kentin Tasarımı ve Toplumsal Yaşam, (çev: S. Sertabiboğlu ve C. Kurultay), İstanbul: Ayrıntı Yayınları, 1999.

TANYELI, Uğur. "Yer, Yer-Olmayan, Naziler, Auge ve Akla Getirdikleri", Arredamento Mimarlık, no. 5, 2012, ss.106-111.

TANYELİ, U., "Sinema ve Mimarlık: Temsiliyet Nesnenin Temsili Sanatın Sanallıkla İfadesi", Arredamento Mimarlık, 11:66, 2001.

TOURAINE, A., Modernliğin Eleştirisi, Modernist İdeoloji, (çev. Hülya Tufan), 4.bs., İstanbul, Yapı Kredi Yayınları, 2002.

VENTURI, Robert, Complexity and Contradiction in Architecture, The Museum of Modern Art, New York, 2002.

WEISHAAR, Schuy R., "Tim Burton's Two Worlds", Masters of the Grotesque, The Cinema of Tim Burton, Terry Gilliam, the Coen Brothers and David Lynch, McFarland \& Company Inc., North Carolina, 2012. 
Sayfa/Page | 148 İGÜSBD Cilt: 3 Sayı: 1 Nisan / April 2016

\section{Summary}

The industrial revolution experienced in 1750 s has caused dramatic changes not only in daily life but also in whole community by changing life style, communication type, relationships, technology, material and particularly new production forms. This era called as "Modern". Modernism emerged with the discourse of innovation in all scales has become a general approach for every "place" and every "time". Thus none-place of modern worlds came up with this. In this study, spatial fiction of critical approach that architecture and cinema form against this situation is examined.

It is aimed to examine the relationship between architecture and cinema through space representation. In this study, with particular reference tables formed by Tanyeli, movie samples are selected by considering both form of use and composing of fiction space for movies only ad together with the real architectural space used in cinema. The spatial relationships in the films examine how the context is used.

In accordance with this, the study assesses how perception of "place", " place identity", "place attachment", and "variance" are transmitted to audience through cinema together with representative space that has come up with concept of "no place", "disidentification" and "alienation". Chosen scene are analysed by taking screenshots on a computer. Then an assessment is made on the represented cinema space using a comparative method.

Movies that examined in this study are categorized into three groups; movies using real space that characterized directly "nonplace", movies using contrast of real and imaginary (fiction) space characterized directly "nonplace" and "movies using real space and event fiction that characterized indirectly "non place".

Terminal movie is selected as example of movies using real space that direcly characterizes non place. In this movie the experience of individual who has no place in space is called no place in line with the definition of Auge's supermodernity age "place". While the movie deals with subject of human who has no place due to the firm system that sticks with in space, it narrates to gained "identity" and "variance" to place by human. In this study terminal movie is selected since it reflects the variability of the concept of nonplace as a result of productivity. In this way the spatial settings and action spaces with regard to living and home are constituted in the station building that is called non-place. 
Tim Burton movies like Edward Scissorshands, Alice in Wonderland, Dead Bride, and Batman Returns are chosen to example of movies using contrast of real and imaginary (fiction) space that directly characterizes "nonplace". This kind of movies uses the place and various alternatives to the place in order to show the chaos and the paradox of the modern world. There is an opposition between these two places as modern and old fashioned places, even surreal places. As for the Burton's movies, he criticises the city and shows how modernism makes it a fabricated production by constructing alternative buildings in real spaces. Space fiction of "Fight club" is another example of movies using real space that indirectly characterizes "nonplace" concept.

Whole buildings, even the home of the movie's main character are becoming same as there is no variance to subject's identity. As a reaction to this case, individuals starting from their own homes protest against all structures called "nonplace" within the system of the 20th century. Despite of all the lights of the city, the places chosen as a new route for them are dark, empty and dilapidated alternative places. In this way individuals stay in freedom and gain their identity in parallel to the whole loss of all fabricated production of urban spaces given the effect of modernism.

Sayfa/Page | 149

İGÜSBD

Cilt: 3 Sayı: 1

Nisan /

April 2016 